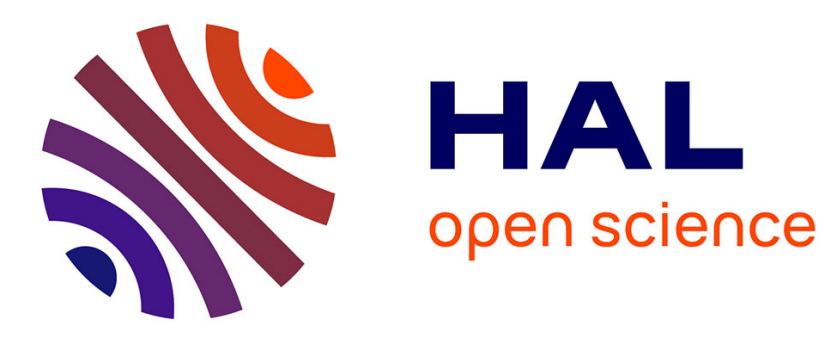

\title{
Mechanisms of action and structure-activity relationships of cytotoxic flavokawain derivatives
}

Charlotte Thieury, Nicolas Lebouvier, Rémy Le Guével, Yann Barguil, Gaëtan

Herbette, Cyril Antheaume, Edouard Hnawia, Yoshinori Asakawa,

Mohammed Nour, Thierry Guillaudeux

\section{To cite this version:}

Charlotte Thieury, Nicolas Lebouvier, Rémy Le Guével, Yann Barguil, Gaëtan Herbette, et al.. Mechanisms of action and structure-activity relationships of cytotoxic flavokawain derivatives. Bioorganic and Medicinal Chemistry, 2017, 25 (6), pp.1817-1829. 10.1016/j.bmc.2017.01.049 . hal-01485126

\section{HAL Id: hal-01485126 \\ https://hal-univ-rennes1.archives-ouvertes.fr/hal-01485126}

Submitted on 4 Jul 2017

HAL is a multi-disciplinary open access archive for the deposit and dissemination of scientific research documents, whether they are published or not. The documents may come from teaching and research institutions in France or abroad, or from public or private research centers.
L'archive ouverte pluridisciplinaire HAL, est destinée au dépôt et à la diffusion de documents scientifiques de niveau recherche, publiés ou non, émanant des établissements d'enseignement et de recherche français ou étrangers, des laboratoires publics ou privés. 


\section{Graphical Abstract}

\section{Mechanisms of Action and Structure- Activity Relationships of Cytotoxic Flavokawain Derivatives}

Charlotte Thieury ${ }^{\mathrm{a},}{ }^{,}$, Nicolas Lebouvier ${ }^{\mathrm{a}}$, Rémy Le Guével ${ }^{2, \#}$, Yann Barguil ${ }^{\mathrm{a}, \mathrm{c}, \#,}$ Gaëtan Herbette $^{\mathrm{d}}$, Cyril Antheaume $^{\mathrm{a}}$, Edouard Hnawia ${ }^{\mathrm{a}}$, Yoshinori Asakawa ${ }^{\mathrm{e}}$, Mohammed Nour ${ }^{\mathrm{a}, \$}$, Thierry Guillaudeux ${ }^{\mathrm{b}, \mathrm{f}, \mathrm{g}, \uparrow}$ ${ }^{a}$ LIVE EA 4243, Université de la Nouvelle-Calédonie, avenue James Cook, BPR4, 98851, Nouméa, NouvelleCalédonie

${ }^{b}$ UMS 3480 CNRS/US INSERM 018 BIOSIT Plateforme ImPACcell, Université de Rennes 1, 2 avenue du Pr Léon Bernard, 35043 Rennes Cedex, France

${ }^{c}$ Laboratoire de Biochimie et d'Hémostase, Hôpital Gaston Bourret, 7 avenue Paul Doumer, 98800 Nouméa, Nouvelle-Calédonie

${ }^{d}$ Spectropole, FR1739 - Faculté de Saint-Jérôme, Université d'Aix-Marseille, 52 Avenue Escadrille Normandie Niemen, 13013 Marseille, France

${ }^{e}$ Faculty of Pharmaceutical Sciences, Tokushima Bunri University, Nishihamahoji-180 Yamashirocho,

Tokushima 770-8514, Japan

'UMR INSERM U917 “Microenvironnement et cancer”, Université de Rennes 1, 2 avenue du Pr Léon Bernard, 35043 Rennes Cedex, France

${ }^{g}$ ER INSERM 440 Université de Rennes 1 “Oncogenesis Stress Signaling”, Centre Eugène Marquis, 35043

Rennes Cedex, France


Click here 


\title{
Mechanisms of Action and Structure-Activity Relationships of Cytotoxic Flavokawain Derivatives
}

\author{
Charlotte Thieury ${ }^{\mathrm{a}, *}$, Nicolas Lebouvier ${ }^{\mathrm{a}}$, Rémy Le Guével ${ }^{\mathrm{b}, \#}$, Yann Barguil ${ }^{\mathrm{a}, \mathrm{c}, \#,}$ Gaëtan Herbette ${ }^{\mathrm{d}}$, Cyril \\ Antheaume $^{\mathrm{a}}$, Edouard Hnawia ${ }^{\mathrm{a}}$, Yoshinori Asakawa ${ }^{\mathrm{e}}$, Mohammed Nour ${ }^{\mathrm{a}, \sharp}$, Thierry Guillaudeux ${ }^{\mathrm{b}, \mathrm{f}, \mathrm{g}, \sharp}$ \\ ${ }^{a}$ LIVE EA 4243, Université de la Nouvelle-Calédonie, avenue James Cook, BPR4, 98851, Nouméa, Nouvelle-Calédonie \\ ${ }^{b}$ UMS 3480 CNRS/US INSERM 018 BIOSIT Plateforme ImPACcell, Université de Rennes 1, 2 avenue du Pr Léon Bernard, 35043 Rennes Cedex, France \\ ${ }^{c}$ Laboratoire de Biochimie et d'Hémostase, Hôpital Gaston Bourret, 7 avenue Paul Doumer, 98800 Nouméa, Nouvelle-Calédonie \\ ${ }^{d}$ Spectropole, FR1739 - Faculté de Saint-Jérôme, Université d'Aix-Marseille, 52 Avenue Escadrille Normandie Niemen, 13013 Marseille, France \\ ${ }^{e}$ Faculty of Pharmaceutical Sciences, Tokushima Bunri University, Nishihamahoji-180 Yamashirocho, Tokushima 770-8514, Japan \\ 'UMR INSERM U917 “Microenvironnement et cancer”, Université de Rennes 1, 2 avenue du Pr Léon Bernard, 35043 Rennes Cedex, France \\ gINSERM 440 Université de Rennes 1 “Oncogenesis Stress Signaling”, Centre Eugène Marquis, 35043 Rennes Cedex, France
}

\section{ABSTRACT}

22 flavokawain derivatives (FKd) were obtained by one step syntheses in order to conduct a SAR study to understand the structural requirements for optimum and selective cytotoxicity. FKd and natural flavokawains A and B found into kava, a South Pacific traditional beverage, were evaluated against nine cancer and one healthy cell lines. The targeted cell cycle phases as well as the effects on the induction of apoptosis and cell cycle protein levels were investigated. Therapeutic improvements (more activity and selectivity) were achieved with FKd compared to natural flavokawains and notably with the $2^{\prime}, 3,4^{\prime}, 6^{\prime}$-tetramethoxychalcone (FKd 19). FKd induced a $\mathrm{G} 1 / \mathrm{S}$ arrest on 553 wild-type cells and an $\mathrm{M}$ arrest on p53 mutant-type, via the upregulation of $\mathrm{p} 21$ and cyclin $\mathrm{B} 1$ proteins, followed by apoptosis. Moreover, FKd exhibited a $24 \mathrm{~h}$-effect on Akt/mTor normal cells versus a $48 \mathrm{~h}$-effect on Akt/mTor up-regulated cells. The SAR study resulted in the conclusion that trimethoxy A-ring allowed the best compromise between cytotoxicity and selectivity, as well as the substitution of the meta position on the Bring and the use of halogens substituents.

* Corresponding author. Tel.: +687 260 760; e-mail: thieury.c@live.fr

\#These authors act as equivalent contributors.

$\$$ These authors act as co-senior equivalent authors. 


\section{Introduction}

Kava is a traditional psychotropic beverage made from the rhizomes of Piper methysticum G. Forst, a cultivated shrub indigenous to the South Pacific Islands. Previous epidemiological studies have shown an inverse relationship between cancer incidence and kava consumption. Indeed, very low incidences of many cancers (lung and colorectal cancers) were observed in the highest kava-drinking South Pacific Islands such as Fiji, Vanuatu and Western Samoa. Moreover, an uncustomary gender ratio of cancer incidences (more cancers in women than men) is observed in these countries, while the percentage of men is higher than women in the kava-drinking population. ${ }^{1,2}$

Following these findings, phytochemical studies revealed that the kavalactones and chalcones were the two main classes of compounds found in the rhizome extracts. The three major chalcones, flavokawains $\mathrm{A}, \mathrm{B}$ and $\mathrm{C}$, exhibited antitumoral activities. Flavokawain A (FKA) ${ }^{3-11}$ has been described to have in vitro and in vivo cytotoxic activities against several cancers (bladder, breast, blood, ovary, uterus and cervix, lung, liver, colon, kidney and nasopharynx) with differentiated activities depending on the p53 status: G1/S arrest on p53 wild-type cells mediated in part by p21 up-regulation, and G2/M arrest on p53mutant type cells mediated among other things by cyclin B1 upregulation. FKA is a potent inducer of apoptosis, though the activation of caspase 3 , which also halted the migration and invasion process as well as angiogenesis. Flavokawain B $(\mathrm{FKB})^{3,7,10,12-24}$ has been described to exhibit both in vitro and in vivo anticancer activity against bladder, blood, bone, colon, lung, liver, ovarian, breast, cervical, nasopharyngeal, prostate, skin, synovial and oral cancers. In one normal cell line interestingly, FKB showed very minimal cytotoxic effect. FKB caused G2/M or G1/S phase cell cycle arrest depending on the cancer cell lines. The G2/M arrest was observed notably by reductions in the level of cyclin B1 and increases in the levels of $\mathrm{p} 21$ and $\mathrm{p} 53$. Apoptosis induced by FKB resulted in the activation of the mitochondrial apoptotic pathway, up regulation of apoptotic proteins as caspase 3 and down-regulation of anti-apoptotic markers. Moreover, FKB is able to decrease the ability of migration and invasion of cancer cells as well as angiogenesis. Flavokawain C (FKC) $)^{10,22,25,26}$ has an in vitro cytotoxic activity against bladder, liver, lung, colorectal and blood cancer cell lines by induction of intrinsic and extrinsic apoptosis via up-regulation of the levels of proapoptotic proteins and death receptors, and via down-regulation of the levels of anti-apoptotic proteins. FKC caused G1/S phase cell cycle arrest accompanied by a decrease of the expression of phosphorylated Akt and an increase of the level of p21. Also, the three natural FKA, B and C exert anti-inflammatory activities as inhibition of nuclear factor $\mathrm{\kappa B}$ pathways which can play a role in anticancer activities. $^{15,27-29}$

Only these three flavokawains occur naturally in plants. However, few syntheses have been performed to obtain flavokawain derivative structures in order to improve a promising cytotoxic activity of natural flavokawains. Previous studies have described structure-activities relationship of flavokawain derivatives $(\mathrm{FKd})$ on proteins involved in cancer development (melanin, tyrosinase, glutathione, Nrf2, HIF-1, NF- $\kappa \mathrm{B}$, cancer breast resistance protein, iNOS, interleukin-1) and on six cancer cell lines (TK-10, MCF-7, HT-29, HepG2, HeLa, A549). ${ }^{5,6,28,30-37}$

In this study, we investigated the in vitro cytotoxic effects of twenty-two FKd of which 14 were tested for the first time for their cytotoxic effects. Tests were performed on nine cancer cell lines: $\mathrm{HuH} 7$ (hepatocellular carcinoma cells), $\mathrm{CaCo}-2$ (colorectal adenocarcinoma), MDA-MB-231 (breast adenocarcinoma), HCT116 (colorectal carcinoma), PC3 (prostatic adenocarcinoma), NCI-H727 (lung carcinoid), HaCaT (immortal keratinocyte), MCF-7 (breast adenocarcinoma) and RL (NonHodgkin's lymphoma) of which eight were included in a SAR study for the first time, and one normal human fibroblastic cell line. The molecular pathway targeted by these compounds was identified (targeted cell cycle phase, induction of apoptosis, effects on p21 and cyclin B1). The influence of the mutational status of the cell lines on the cytotoxic activity of FKd was confirmed in the case of $\mathrm{p} 53$ protein and highlighted in the case of $\mathrm{Akt} / \mathrm{mT}$ or pathway. A structure-activity relationship analysis was performed in order to improve the structural requirements for optimum activity.

\section{Materials and methods}

\subsection{General procedures for synthesis of FKd}

In $20 \mathrm{~mL}$ of $\mathrm{MeOH}$, corresponding acetophenones $(1.5 \mathrm{mmol}$, 2-hydroxy-4,6-dimethoxyacetophenone for compounds 1-10, and 2,4,6-trimethoxy-2-hydroxyacetophenone for compounds 11-22), benzaldehyde derivatives $(1.5 \mathrm{mmol})$ and $\mathrm{NaOH}(2.5$ equivalent of acetophenone) were dissolved. The reaction mixture was stirred at room temperature until the completion of the reaction which was monitored by TLC. The excess of $\mathrm{NaOH}$ was neutralized by addition of $\mathrm{HCl} 0.1 \mathrm{M}$. Compounds $\mathbf{6 , 7}$ and 19 were directly purified by Sephadex column chromatography. For the others, $\mathrm{MeOH}$ was evaporated and the solid residue was dissolved in $\mathrm{CH}_{2} \mathrm{Cl}_{2}(50 \mathrm{~mL})$ and washed with distilled water (3 $\times 50 \mathrm{~mL}$ ). The organic phase was dried with $\mathrm{MgSO}_{4}$, filtered and $\mathrm{CH}_{2} \mathrm{Cl}_{2}$ was removed under vacuum. Finally, FKd were purified by column chromatography or by crystallization in $\mathrm{MeOH}$ or EtOAc. Purity of FKd reached at least $95 \%$, as confirmed by HPLC. All chemicals were purchased from Sigma-Aldrich (Saint-Louis, MO, USA) and HPLC quality solvents from Fischer Chemicals (Leicestershire, UK). Mass spectral (MS) analysis was carried on a Bruecker Esquire HCT Ultra MS instrument equipped with an electrospray ion source. High resolution mass spectral (HRMS) analysis was carried on a Waters SYNAPT G2 HDMS instrument equipped with an atmospheric pressure ionization source. NMR analyses were performed on a Bruecker Avance III spectrometer. Melting points were determined on an Electrothermal 9100 apparatus.

\subsection{Structure characterization}

Structure elucidations were down by comparison of ${ }^{1} \mathrm{H}$ and ${ }^{13} \mathrm{C}$ spectrum with literature. All these NMR data are presented in supplementary data (Material M1). FKd 6, 10, 14, 16, 19 and 21 were not previously identified by their NMR data (new or not characterized). ${ }^{1} \mathrm{H}$ and ${ }^{13} \mathrm{C}$ NMR data are given in the materials and methods section. Key ${ }^{1} \mathrm{H}-{ }^{1} \mathrm{H}$ COSY and $\mathrm{HMBC}$ are presented in the supplementary data (Figure F1).

\subsection{1. (E)-1 - (2 - hydroxy -4,6-dimethoxyphenyl) -3 - (4-methoxyphenyl)prop-2-en-1-one or Flavokawain A (1)}

Yellow crystals, Yield (Y): $98 \%$, Melting point: (MP) $110^{\circ} \mathrm{C}$. ${ }^{1} \mathrm{H}$ and ${ }^{13} \mathrm{C}$ spectrum were consistent with literature. ${ }^{38}$ MS-ESI $m / z$ : Anal. Calc. for $\mathrm{C}_{18} \mathrm{H}_{18} \mathrm{O}_{5}[\mathrm{M}+\mathrm{H}]^{+} 315$, found 315 .

\subsection{2. (E)-1-(2-hydroxy-4,6-dimethoxyphenyl) -3- phenylprop-2-en-1-one or Flavokawain B (2)}

Yellow crystals, Y: $38 \%$, MP: $89^{\circ} \mathrm{C} .{ }^{1} \mathrm{H}$ and ${ }^{13} \mathrm{C}$ spectrum were consistent with literature. ${ }^{38}$ MS-ESI $\mathrm{m} / \mathrm{z}$ : Anal. Calc. for $\mathrm{C}_{17} \mathrm{H}_{16} \mathrm{O}_{4}[\mathrm{M}+\mathrm{H}]^{+} 285$, found 285; [M-H] 283, found 283 .

2.2.3. (E)-3-(4-chlorophenyl) -1 - (2-hydroxy-4,6dimethoxyphenyl)prop-2-en-1-one (3) 
Yellow crystals, Y: $24 \%$, MP: $158-168^{\circ} \mathrm{C}$. ${ }^{1} \mathrm{H}$ and ${ }^{13} \mathrm{C}$ spectrum were consistent with literature. ${ }^{39}$ MS-ESI $m / z$ : Anal. Calc. for $\mathrm{C}_{17} \mathrm{H}_{15} \mathrm{O}_{4} \mathrm{Cl}[\mathrm{M}-\mathrm{H}]^{-} 317$ and 319 , found 317 and 319 .

2.2.4. (E)-3-(4-brom op henyl)-1-(2-hydroxy-4,6dimethoxyphenyl)prop-2-en-1-one (4)

Yellow crystals, Y: $17 \%$, MP: $165^{\circ} \mathrm{C}$. ${ }^{1} \mathrm{H}$ and ${ }^{13} \mathrm{C}$ spectrum were consistent with literature. ${ }^{38}$ MS-ESI $\mathrm{m} / \mathrm{z}$ : Anal. Calc. for $\mathrm{C}_{17} \mathrm{H}_{15} \mathrm{O}_{4} \mathrm{Br}[\mathrm{M}+\mathrm{H}]^{+} 364$ and 366 , found 364 and 366; [M-H] 362 and 364 , found 362 and 364 .

2.2.5. (E)-3-(4-fluor op he nyl-1 - (2 - hydroxy-4,6dimethoxyphenyl)prop-2-en-1-one (5)

Yellow crystals, Y: $27 \%$, MP: $132{ }^{\circ} \mathrm{C} .{ }^{1} \mathrm{H}$ and ${ }^{13} \mathrm{C}$ spectrum were consistent with literature. ${ }^{38}$ MS-ESI $m / z$ : Anal. Calc. for $\mathrm{C}_{17} \mathrm{H}_{15} \mathrm{O}_{4} \mathrm{~F}[\mathrm{M}-\mathrm{H}]^{-}$301, found 301 .

2.2.6. (E)-4-(3-(2-hydroxy-4,6-dimethoxyphenyl)3-oxoprop-1-en-1-yl)benzoic acid (6)

Yellow crystals, Y: $63 \%$, MP: $250{ }^{\circ} \mathrm{C} .{ }^{1} \mathrm{H}$ NMR (DMSO-d6, $600 \mathrm{MHz}$ ): $\delta 3.81$ (s, 3H, 4'- $\left.\mathrm{OCH}_{3}\right), 3.89$ (s, 3H, 6'- $\left.\mathrm{OCH}_{3}\right), 6.12$ (d, J=2.2Hz, 1H, H-3'), 6.15 (d, J=2.2Hz, 1H, H-5'), 7.64 (d, $\mathrm{J}=15.9 \mathrm{~Hz}, 1 \mathrm{H}, \mathrm{H}-\beta), 7.81(\mathrm{~d}, \mathrm{~J}=15.9 \mathrm{~Hz}, 1 \mathrm{H}, \mathrm{H}-\alpha), 7.82(\mathrm{~d}$, $\mathrm{J}=8.2 \mathrm{~Hz}, 2 \mathrm{H}, \mathrm{H}-2,6), 7.98(\mathrm{~d}, \mathrm{~J}=8.2 \mathrm{~Hz}, 2 \mathrm{H}, \mathrm{H}-3,5) .{ }^{13} \mathrm{C} \mathrm{NMR}$ (DMSO-d6, $600 \mathrm{MHz}): \delta 55.85\left(4^{\prime}-\mathrm{OCH}_{3}\right), 56.41\left(6 '-\mathrm{OCH}_{3}\right)$, 91.27(C-5'), 94.05(C- 3'), 106.55 (C-1'), 128.62 (C-2,6), 129.84 (C- $\alpha), 130.06$ (C-3,5), 132.06 (C-4), 139.06 (C-1), 140.79 (C- $\beta)$, 162.10 (C-6'), 165.54 (C-2'), 165.92 (C-4'), 167.01 (-COOH), $192.31(-\mathrm{CO}) .{ }^{1} \mathrm{H}^{1}{ }^{1} \mathrm{H}$ COSY and HMBC analysis are presented in figure S1. HRMS-ESI (+) $m / z$ : Anal. Calc. for $\mathrm{C}_{18} \mathrm{H}_{16} \mathrm{O}_{6}[\mathrm{M}+\mathrm{H}]^{+}$ 329.1020 , found 329.1020 .

2.2.7. (E)-3-(4-(dimethylamino)phenyl)-1-(2hydroxy-4,6-dimethoxyphenyl)prop-2-en-1-one (7)

Orange crystals, Y: $83 \%$, MP: $153{ }^{\circ} \mathrm{C} .{ }^{1} \mathrm{H}$ and ${ }^{13} \mathrm{C}$ spectrum were consistent with literature. ${ }^{7}$ MS-ESI $\mathrm{m} / \mathrm{z}$ : Anal. Calc. for $\mathrm{C}_{19} \mathrm{H}_{21} \mathrm{O}_{4} \mathrm{~N}[\mathrm{M}+\mathrm{H}]^{+} 328$, found 328; [M-H] $]^{-} 326$, found 326 .

2.2.8. (E)-1-(2-hydroxy-4,6-dimethoxyphenyl)-3(3-methoxyphenyl)prop-2-en-1-one (8)

Yellow crystals, Y: $66 \%$, MP: $100{ }^{\circ} \mathrm{C}$. ${ }^{1} \mathrm{H}$ and ${ }^{13} \mathrm{C}$ spectrum were consistent with literature. ${ }^{39}$ MS-ESI $\mathrm{m} / \mathrm{z}$ : Anal. Calc. for $\mathrm{C}_{18} \mathrm{H}_{18} \mathrm{O}_{5}[\mathrm{M}+\mathrm{H}]^{+}$315, found 315; [M-H] 313 , found 313 .

2.2.9. (E)-1-(2-hydroxy-4,6-dimethoxyphenyl)-3(2-methoxyphenyl)prop-2-en-1-one (9)

Orange crystals, Y: $41 \%$, MP: $113{ }^{\circ} \mathrm{C} .{ }^{1} \mathrm{H}$ and ${ }^{13} \mathrm{C}$ spectrum were consistent with literature. ${ }^{39}$ MS-ESI $m / z$ : Anal. Calc. for $\mathrm{C}_{18} \mathrm{H}_{18} \mathrm{O}_{5}[\mathrm{M}+\mathrm{H}]^{+} 315$, found 315; [M-H] $]^{-} 313$, found 313 .

2.2.10. (E)-1-(2-hydroxy-4,6-dimethoxyphenyl)-3(2-(methylthiophenyl)prop-2-en-1-one (10)

Orange crystals, Y: $91 \%$, MP: $98^{\circ} \mathrm{C} .{ }^{1} \mathrm{H}$ NMR $\left(\mathrm{CDCl}_{3}, 600\right.$ $\mathrm{MHz}): \delta 2.47\left(\mathrm{~s}, 3 \mathrm{H}, 2-\mathrm{SCH}_{3}\right), 3.82\left(\mathrm{~s}, 3 \mathrm{H}, 4^{\prime}-\mathrm{OCH}_{3}\right), 3.88(\mathrm{~s}$, $\left.3 \mathrm{H}, 6{ }^{\prime}-\mathrm{OCH}_{3}\right), 5.94$ (d, J=2.4Hz, 1H, H-5'), 6.09 (d, J=2.4Hz, 1H, H-3'), 7.19 (m, 1H, H-5), 7.32 (m, 2H, H-3,4), 7.59 (brd, $\mathrm{J}=8.0 \mathrm{~Hz}, 1 \mathrm{H}, \mathrm{H}-6), 7.81(\mathrm{~d}, \mathrm{~J}=15.6 \mathrm{~Hz}, 1 \mathrm{H}, \mathrm{H}-\alpha), 8.24(\mathrm{~d}$, $\mathrm{J}=15.6 \mathrm{~Hz}, 1 \mathrm{H}, \mathrm{H}-\beta) .{ }^{13} \mathrm{C} \mathrm{NMR}\left(\mathrm{CDCl}_{3}, 600 \mathrm{MHz}\right): \delta 16.97(2-$ $\left.\mathrm{SCH}_{3}\right), 55.81\left(4^{\prime}-\mathrm{OCH}_{3}\right), 56.09\left(6^{\prime}-\mathrm{OCH}_{3}\right), 91.44\left(\mathrm{C}^{-} 5^{\prime}\right), 94.00$ (C-3'), 106.58 (C-1'), 125.77 (C-5), 127.53 (C-6), 127.69 (C-3), 129.47 (C- $\alpha), 130.23$ (C-4), 135.16 (C-1), 139.48 (C- $\beta), 140.10$ (C-2), 162.72 (C-6'), 166.45 (C-4'), 168.65 (C-2'), 192.76 (-CO). ${ }^{1} \mathrm{H}-{ }^{1} \mathrm{H}$ COSY and $\mathrm{HMBC}$ analysis are presented in figure $\mathrm{S} 1$. HRMS-ESI (+) $m / z$ : Anal. Calc. for $\mathrm{C}_{18} \mathrm{H}_{18} \mathrm{O}_{4} \mathrm{~S} \quad[\mathrm{M}+\mathrm{H}]^{+}$ 331.0999 , found 331.1003 .

2.2.11. (E)-3-(4-methoxyphenyl)-1-(2,4,6trimethoxyphenyl)prop-2-en-1-one (11)
Yellow crystals, Y: $89 \%$, MP: $119^{\circ} \mathrm{C} .{ }^{1} \mathrm{H}$ and ${ }^{13} \mathrm{C}$ spectrum were consistent with literature. ${ }^{34}$ MS-ESI $m / z$ : Anal. Calc. for $\mathrm{C}_{19} \mathrm{H}_{20} \mathrm{O}_{5}[\mathrm{M}+\mathrm{H}]^{+} 329$, found 329 .

2.2.12. (E)-3-phenyl-1- $(2,4,6-$

trimethoxyphenyl)prop-2-en-1-one (12)

Yellow crystals, Y: $79 \%$, MP: $63^{\circ} \mathrm{C} .{ }^{1} \mathrm{H}$ and ${ }^{13} \mathrm{C}$ spectrum were consistent with literature. ${ }^{37}$ MS-ESI $\mathrm{m} / \mathrm{z}$ : Anal. Calc. for $\mathrm{C}_{18} \mathrm{H}_{18} \mathrm{O}_{4}[\mathrm{M}+\mathrm{H}]^{+} 299$, found 299 .

\subsubsection{3. (E)-3-(4-chlorophenyl)-1-(2,4,6-} trimethoxyphenyl)prop-2-en-1-one (13)

Yellow crystals, Y: $48 \%$, MP: $130{ }^{\circ} \mathrm{C} .{ }^{1} \mathrm{H}$ and ${ }^{13} \mathrm{C}$ spectrum were consistent with literature. ${ }^{34} \mathrm{MS}-\mathrm{ESI} \mathrm{m} / \mathrm{z}$ : Anal. Calc. for $\mathrm{C}_{18} \mathrm{H}_{17} \mathrm{O}_{4} \mathrm{Cl}[\mathrm{M}+\mathrm{H}]^{+} 333$ and 335 , found 333 and 335 .

\subsubsection{4. (E)-3-(4-bromophenyl)-1-(2,4,6-}

trimethoxyphenyl)prop-2-en-1-one (14)

Yellow crystals, Y: $74 \%, \mathrm{MP}: 116^{\circ} \mathrm{C} .{ }^{1} \mathrm{H}$ NMR $\left(\mathrm{CDCl}_{3}, 600\right.$ $\mathrm{MHz}): \delta 3.75\left(\mathrm{~s}, 6 \mathrm{H}, 2^{\prime}, 6^{\prime}-\mathrm{OCH}_{3}\right), 3.84\left(\mathrm{~s}, 3 \mathrm{H}, 4^{\prime}-\mathrm{OCH}_{3}\right), 6.14$ (s, 2H, H-3',5'), $6.92(\mathrm{~d}, \mathrm{~J}=16.2 \mathrm{~Hz}, 1 \mathrm{H}, \mathrm{H}-\alpha), 7.28(\mathrm{~d}, \mathrm{~J}=16,2 \mathrm{~Hz}$, $1 \mathrm{H}, \mathrm{H}-\beta), 7.36(\mathrm{~d}, \mathrm{~J}=8.5 \mathrm{~Hz}, 2 \mathrm{H}, \mathrm{H}-2,6), 7.47$ (d, J=8.5Hz, 2H, H$3,5) .{ }^{13} \mathrm{C} \mathrm{NMR}\left(\mathrm{CDCl}_{3}, 600 \mathrm{MHz}\right): \delta 56.11\left(4^{\prime}-\mathrm{OCH}_{3}\right), 56.24$ (2',6'- $\left.\mathrm{OCH}_{3}\right), 90.96$ (C-3',5'), 111.96 (C-1'), 124.56 (C-4), $129.67(\mathrm{C}-\alpha), 129.95$ (C-2,6), 132.25 (C-3,5), 134.22 (C-1), 142.55 (C- $\beta$ ), 159.16 (C-2', 6'), 162.79 (C-4'), 193.96 (-CO). ${ }^{1} \mathrm{H}-$ ${ }^{1} \mathrm{H}$ COSY and $\mathrm{HMBC}$ analysis are presented in figure $\mathrm{S} 1$. HRMS-ESI (+) $m / z$ : Anal. Calc. for $\mathrm{C}_{18} \mathrm{H}_{17} \mathrm{O}_{4} \mathrm{Br}[\mathrm{M}+\mathrm{H}]^{+}$ 377.0383 and 379.0365 , found 377.0386 and 379.0365 .

2.2.15. (E)-3-(4-fluor op he nyl)-1-(2,4,6trimethoxyphenyl)prop-2-en-1-one (15)

Yellow crystals, Y: $33 \%$, MP: $109{ }^{\circ} \mathrm{C}$. ${ }^{1} \mathrm{H}$ and ${ }^{13} \mathrm{C}$ spectrum were consistent with literature. ${ }^{40}$ MS-ESI $\mathrm{m} / \mathrm{z}$ : Anal. Calc. for $\mathrm{C}_{18} \mathrm{H}_{17} \mathrm{O}_{4} \mathrm{~F}[\mathrm{M}+\mathrm{H}]^{+} 317$, found 317; [M-H] 315, found 315 .

2.2.16. (E)-4-(3-0х0-3- $(2,4,6-$

trimethoxyphenyl)prop-1-en-1-yl)benzoic acid (16)

Yellow crystals, Y: $100 \%$, MP: $210^{\circ} \mathrm{C} .{ }^{1} \mathrm{H}$ NMR $\left(\mathrm{CDCl}_{3}, 600\right.$ $\mathrm{MHz}): \delta 3.77$ (s, 6H, 2',6'- $\left.\mathrm{OCH}_{3}\right), 3.85$ (s, 3H, 4'- $\left.-\mathrm{OCH}_{3}\right), 6.14$ (s, 2H, H-3', 5'), 7.03 (d, J=15.8Hz, $1 \mathrm{H}, \mathrm{H}-\beta), 7.40$ (d, J=15.8Hz, $1 \mathrm{H}, \mathrm{H}-\alpha), 7.59$ (d, J=8.3Hz, 2H, H-2,6), 8.07 (d, J=8.3Hz, 2H, H3,5). ${ }^{13} \mathrm{C} \mathrm{NMR}\left(\mathrm{CDCl}^{3}, 600 \mathrm{MHz}\right): \delta 55.71\left(4^{\prime}-\mathrm{OCH}_{3}\right), 56.19$ (2',6'- $\left.\mathrm{OCH}_{3}\right), 91.01$ (C-3',5'), $\left.111.84\left(\mathrm{C}^{\prime}\right)^{\prime}\right), 128.45(\mathrm{C}-2,6)$, 130.37 (C-4), 130.84 (C-3,5), 131.52 (C- $\alpha), 140.52$ (C-1), 141.91 (C- $\beta$ ), 159.32 (C-2',6'), 162.97 (C-4'), 170.71 (-COOH), 193.69 (-CO). ${ }^{1} \mathrm{H}-{ }^{1} \mathrm{H}$ COSY and $\mathrm{HMBC}$ analysis are presented in figure S1. HRMS-ESI (+) $m / z$ : Anal. Calc. for $\mathrm{C}_{19} \mathrm{H}_{18} \mathrm{O}_{6}[\mathrm{M}+\mathrm{H}]^{+}$ 343.1176, found 343.1176 .

\subsubsection{7. (E)-3-(4-(dimethylamino)phenyl)-1-}

(2,4,6-trimethoxyphenyl)prop-2-en-1-one (17)

Yellow crystals, Y: $100 \%$, MP: $153{ }^{\circ} \mathrm{C}$. ${ }^{1} \mathrm{H}$ and ${ }^{13} \mathrm{C}$ spectrum were consistent with literature. ${ }^{33}$ MS-ESI $\mathrm{m} / \mathrm{z}$ : Anal. Calc. for $\mathrm{C}_{20} \mathrm{H}_{23} \mathrm{O}_{4} \mathrm{~N}[\mathrm{M}+\mathrm{H}]^{+} 342$, found 342 .

\subsubsection{8. (E)-3-(4-nitrop henyl)-1-(2,4,6-}

trimethoxyphenyl)prop-2-en-1-one (18)

Brownish crystals, Y: $47 \%$, MP: $159{ }^{\circ} \mathrm{C} .{ }^{1} \mathrm{H}$ and ${ }^{13} \mathrm{C}$ spectrum were consistent with literature. ${ }^{34}$ MS-ESI $m / z$ : Anal. Calc. for $\mathrm{C}_{18} \mathrm{H}_{17} \mathrm{O}_{6} \mathrm{~N}[\mathrm{M}+\mathrm{H}]^{+} 344$, found 344 .

\subsubsection{9. (E)-3-(3-methoxyphenyl $)-1-(2,4,6$ -} trimethoxyphenyl)prop-2-en-1-one (19)

Yellow crystals, Y: $72 \%$, MP: $190{ }^{\circ} \mathrm{C} .{ }^{1} \mathrm{H}$ NMR $\left(\mathrm{CDCl}_{3}, 600\right.$ $\mathrm{MHz}$ ): $\delta 3.75$ (s, 6H, 2',6'- $\left.\mathrm{OCH}_{3}\right), 3.80$ (s, 3H, 4'- $\left.\mathrm{OCH}_{3}\right), 3.84$ $\left(\mathrm{s}, 3 \mathrm{H}, 3-\mathrm{OCH}_{3}\right), 6.14(\mathrm{~s}, 2 \mathrm{H}, \mathrm{H}-3$ ', 5'), $6.90(\mathrm{dd}, \mathrm{J}=8.1 \mathrm{~Hz}$, $\mathrm{J}=2.3 \mathrm{~Hz}, 1 \mathrm{H}, \mathrm{H}-4), 6.92$ (d, J=16.1Hz, 1H, H- $\alpha$ ), 7.02 (brs, $1 \mathrm{H}$, 
H-2), 7.09 (brd, J=7.6Hz, 1H, H-6), 7.26 (brt, J=7.8Hz, 1H, H-5), $7.30(\mathrm{~d}, \mathrm{~J}=16.1 \mathrm{~Hz}, 1 \mathrm{H}, \mathrm{H}-\beta) .{ }^{13} \mathrm{C} \mathrm{NMR}\left(\mathrm{CDCl}_{3}, 600 \mathrm{MHz}\right): \delta$ $55.53\left(4^{\prime}-\mathrm{OCH}_{3}\right), 55.69\left(3-\mathrm{OCH}_{3}\right), 56.16\left(2^{\prime}, 6{ }^{\prime}-\mathrm{OCH}_{3}\right), 90.96$ (C-3',5'), 112.04 (C-1'), 113.31 (C-2), 116.35 (C-4), 121.34 (C6), $129.55(\mathrm{C}-\alpha), 129.99(\mathrm{C}-5), 136.65(\mathrm{C}-1), 144.21(\mathrm{C}-\beta)$, 159.11 (C-2',6'), 160.07 (C-3), 162.68 (C-4'), 192.42 (-CO). ${ }^{1} \mathrm{H}-$ ${ }^{1} \mathrm{H}$ COSY and $\mathrm{HMBC}$ analysis are presented in figure $\mathrm{S} 1$. HRMS-ESI (+) $m / z$ : Anal. Calc. for $\mathrm{C}_{19} \mathrm{H}_{20} \mathrm{O}_{5}[\mathrm{M}+\mathrm{H}]^{+} 329.1384$, found 329.1384 .

\subsubsection{0. (E)-3-(2-methoxyphenyl)-1-(2,4,6- trimethoxyphenyl)prop-2-en-1-one (20)}

Yellow crystals, Y: $17 \%$, MP: $72{ }^{\circ} \mathrm{C}$. ${ }^{1} \mathrm{H}$ and ${ }^{13} \mathrm{C}$ spectrum were consistent with literature. ${ }^{34}$ MS-ESI $m / z$ : Anal. Calc. for $\mathrm{C}_{19} \mathrm{H}_{20} \mathrm{O}_{5}[\mathrm{M}+\mathrm{H}]^{+} 329$, found 329 .

\subsubsection{1. (E)-3-(2-(methylthio $)$ phenyl $)-1-(2,4,6-$ trimethoxyphenyl)prop-2-en-1-one (21)}

Yellow crystals, Y: $27 \%$, MP: $80{ }^{\circ} \mathrm{C} .{ }^{1} \mathrm{H}$ NMR $\left(\mathrm{CDCl}_{3}, 600\right.$ MHz): $\delta 2.39$ (s, 3H, 2-SCH$)_{3}$ ), 3.75 (s, 6H, 2',6'- $\left.\mathrm{OCH}_{3}\right), 3.84$ (s, $\left.3 \mathrm{H}, 4^{\prime}-\mathrm{OCH}_{3}\right), 6.15$ (s, 2H, H-3',5'), 6.84 (d, J=15.7Hz, 1H, Ha), 7.16 (brt, J=7.2Hz, 1H, H-5), 7.27 (m, 1H, H-3), $7.29(\mathrm{~m}, 1 \mathrm{H}$, $\mathrm{H}-4), 7.57$ (brd, J=7.8Hz, 1H, H-6), 7.83 (d, J=15.7Hz, $1 \mathrm{H}, \mathrm{H}-\beta)$. ${ }^{13} \mathrm{C}$ NMR $\left(\mathrm{CDCl}_{3}, 600 \mathrm{MHz}\right): \delta 16.78\left(2-\mathrm{SCH}_{3}\right), 55.99$ (4'$\left.\mathrm{OCH}_{3}\right), 56.13\left(2^{\prime}, 66^{\prime}-\mathrm{OCH}_{3}\right), 90.90\left(\mathrm{C}^{\prime} 3^{\prime}, 5^{\prime}\right), 111.75$ (C-1'), 125.84 (C-5), 127.43 (C-6), 127.61 (C-3), 130.33 (C-4), 130.87 $(\mathrm{C}-\alpha), 134.57$ (C-1), 139.55 (C-2), 141.67 (C- $\beta), 158.99$ (C2',6'), 162.57 (C-4'), 194.81 (-CO). ${ }^{1} \mathrm{H}^{-}{ }^{1} \mathrm{H}$ COSY and HMBC analysis are presented in figure 1 . HRMS-ESI $(+) \mathrm{m} / z$ : Anal. Calc. for $\mathrm{C}_{19} \mathrm{H}_{20} \mathrm{O}_{4} \mathrm{~S}[\mathrm{M}+\mathrm{H}]^{+}$345.1155, found 345.1145.

\subsubsection{2. (E)-3-(4-hydroxyphenyl) -1-(2,4,6-} trimethoxyphenyl)prop-2-en-1-one (22)

Yellow crystals, Y: $79 \%$, MP: $111{ }^{\circ} \mathrm{C} .{ }^{1} \mathrm{H}$ and ${ }^{13} \mathrm{C}$ spectrum were consistent with literature. ${ }^{34}$ ESI $(\mathrm{m} / \mathrm{z}) 315[\mathrm{M}+\mathrm{H}]^{+}, 313[\mathrm{M}-$ $\mathrm{H}]$.

\subsection{Chemicals}

Hoescht 33342 reagent was purchased from Sigma-Aldrich (Saint-Louis, MO, USA) as were formaldehyde, triton X-100, McCoy's, EMEM and RPMI. Bromodeoxyuridine (BrdU) was purchased from Amersham (Buckinghamshire, UK), BrdU primary antibody from Abcam (Cambridge, UK), phosphohistone H3 (PHH3) antibody from Millipore (Molsheim, FR) as normal goat serum and active caspase 3 (CASP3), cyclin B1 antibody from NovusBio (Denver, CO, USA). Secondary coupledfluorophore antibodies were purchased from KPL (Gaithersburg, MD, USA). Roscovitin and Pi103, PBS and DMEM, L-glutamine were purchased from Gibco (Carlsbad, CA, USA). Foetal Bovine Serum (FBS) was purchased from GE Healthcare (Little Chalfont, UK) and penicillin-streptomycin from Life technologies (Carlsbad, CA, USA) as p21 primary antibody and propidium iodide (PI). YO-PRO ${ }^{\circledR}-1$ was purchased from Molecular Probes (Eugene, OR, USA).

\subsection{Cell culture}

Skin diploid fibroblastic cells were purchased from BIOPREDIC International Company (Rennes, FR). HuH7, Caco2, MDA-MB-231, HCT116, PC3, HaCaT, NCI-H727, MCF-7 and RL cell lines were obtained from the ECACC collection (Porton, UK). Cells were grown according to ECACC recommendations in DMEM for HuH7, MDA-MB-231, HaCaT and fibroblast, in EMEM for CaCo-2 and MCF-7, in McCoy's for HCT116 and in RPMI for PC3, NCI-H727 and RL at $37^{\circ} \mathrm{C}$ and $5 \% \mathrm{CO}_{2}$. All culture mediums were added with $10 \%$ of FBS, $1 \%$ of penicillin-streptomycin and $2 \mathrm{mM} \mathrm{L}$-glutamine.

\subsection{Cell viability assay}

Compounds were solubilized in DMSO at a concentration of $50 \mathrm{mM}$. These solutions were then diluted with medium to the desired concentration while maintaining a DMSO final concentration at less than $0.25 \%$. Cell viability assays were performed in two phases: a preliminary screening at a unique dose of each compound (final well concentration $50 \mu \mathrm{M}$ ) and for the interesting compounds (percentage of viability $<50 \%$ ), an $\mathrm{IC}_{50}$ determination test with increasing concentrations of each compound (final well concentrations $0.21 \mu \mathrm{M}-0.62 \mu \mathrm{M}-1.85$ $\mu \mathrm{M}-5.56 \mu \mathrm{M}-16.67 \mu \mathrm{M}-50 \mu \mathrm{M})$.

Cells were plated in 96 wells at a number of 4000 cells/well except for HCT116 and MCF-7 cell lines for which 2000 cells/well were plated because of their quick growth (twice as fast), and for RL cell line for which 20000 cells/well were plated because of their five times slower growth. Twenty-four hours after seeding, cells were exposed to each compound. After $48 \mathrm{~h}$ of treatment, cells were washed in PBS and fixed in cooled $95 \%$ ethanol $/ 5 \%$ acetic acid or in $4 \%$ paraformaldehyde $(60 \mu \mathrm{L}$ during 24 minutes), except for RL cell line. Then, the nuclei were stained with Hoechst 33342 (dilution 1/1000, 1 hour). Image acquisitions and analysis were performed in $80 \mu \mathrm{L}$ of PBS using a Cellomics ArrayScan VTI/HCS Reader (ThermoScientific). For $\mathrm{RL}$ cell line, cells were let to settle out 15 minutes at $32^{\circ} \mathrm{C}$ and $5 \% \mathrm{CO}_{2}$ before image acquisition. The survival percentages were calculated as the number of cells after compound treatment over the number of cells after DMSO treatment. According to doseresponse curves, the $\mathrm{IC}_{50}$ values were determined graphically, as described by the NCI. ${ }^{41}$

\subsection{PHH3 antibody labeling}

After fixation, cells were co-stained with Hoescht dye and primary antibody phospho-histone H3 (Ser10) (dilution 1/5000, 2 hours), and then with secondary coupled-fluorophore antibody detecting primary antibody (dilution $1 / 500,1$ hour). The mitotic index was calculated as the number of mitotic cells, identified by the PHH3-positive staining over the total Hoechst positive cells.

\subsection{BrdU incorporation}

Before fixation, BrdU was added to the culture medium for 90 minutes at $37^{\circ} \mathrm{C}$ and $5 \% \quad \mathrm{CO}_{2}$ (dilution $1 / 1000$ during 30 minutes). After fixation, cells were co-stained with Hoescht dye and BrdU primary antibody (dilution 1/200, 2 hours) and then with secondary coupled-fluorophore antibody detecting primary antibody (dilution 1/500, 1 hour). The percentage of proliferating cells was calculated by the amount of BrdU positive cells over the total Hoechst positive cells.

\section{8. p21, active CASP3 and cyclin $B 1$ antibody labeling}

After fixation, cells were permeabilized and saturated by $5 \%$ normal goat serum and $0.1 \%$ triton $\mathrm{X}-100$ solution $(50 \mu \mathrm{L}$ during 25 minutes). After fixation, cells were co-stained with Hoescht dye and primary antibody $\left(2\right.$ hours at $37^{\circ} \mathrm{C}$ ) p21 (dilution $1 / 800$ ) or active CASP3 (dilution 1/750) or cyclin B1 (dilution 1/200) and then with secondary coupled-fluorophore antibody detecting primary antibody (dilution 1/500, 1 hour). The percentages of labeled cells were calculated as the number of cells, identified by the primary antibody-positive staining over the total Hoechst positive cells.

\subsection{YoPro and PI}

Before fixation, Hoescht dye (dilution 1/4000), YoPro (dilution 1/5000) and PI (dilution 1/1/1000) were added to the culture medium for 30 minutes at $37^{\circ} \mathrm{C}$ and $5 \% \mathrm{CO}_{2}$. The 
percentage of early apoptotic cells was calculated by the amount of YoPro-positive cells over the total Hoechst positive cells and the percentage of late apoptotic and necrotic cells was calculated by the amount of PI-positive cells over the total Hoechst positive cells.

\section{Results}

\subsection{Synthesis}

Twenty-two FKd were synthesized by base catalyzed ClaisenSchmidt condensation from selected benzaldehydes and acetophenones according to the general synthetic procedure given in figure 1 . FKd were categorized into two series according to their substitutions on ring A. The first series corresponded to chalcones with the natural 2-hydroxy-4,6-dimethoyphenyl A-ring moiety (compounds 1-10) where compounds 1 and 2 are respectively FKA and FKB. The last natural FKd, FKC, could not be synthesized by the same procedure and was not included in this study. The second series had a 2,4,6-trimethoxyphenyl Aring (compounds 11-22). Pharmacomodulations on the B-ring consisted of the introduction of halogens $(\mathrm{F}, \mathrm{Cl}, \mathrm{Br})$, donating groups $\left(\mathrm{OH}, \mathrm{OCH}_{3}, \mathrm{SCH}_{3}, \mathrm{~N}\left(\mathrm{CH}_{3}\right)_{2}\right)$ and withdrawing groups in different positions $\left(\mathrm{NO}_{2}, \mathrm{COOH}\right)$. All synthesized compounds are listed in figure 2.

\subsection{Cytotoxic activities against cancer cell lines}

\subsubsection{Cell viability assay}

Cell viabilities of normal human fibroblasts and nine cancer cell lines (HuH7, CaCo-2, MDA-MB-231, HCT116, PC3, NCI$\mathrm{H} 727, \mathrm{HaCaT}, \mathrm{MCF}-7$ and $\mathrm{RL}$ ) in the presence of FKd at a single dose of $50 \mu \mathrm{M}$ were evaluated. The percentages of cell survival (PS) after treatment by FKd were determined (Table S1, supplementary data). For FKd inducing a PS $\leq 50 \%$, quantifications of the activities were performed by determining their $\mathrm{IC}_{50}$. This value corresponded to the concentration of a given compound inducing a PS equal to $50 \%$. Results are shown in table 1; in pale grey, FKd showing an $\mathrm{IC}_{50} \leq 10 \mu \mathrm{M}$ and in dark grey, FKd showing an $\mathrm{IC}_{50} \leq 5 \mu \mathrm{M}$.

Figures $2 \mathrm{a}$ and $2 \mathrm{~b}$ give the example of roscovitine and compound 19 treatments on HCT116 cell line compared to DMSO treatment (control)

Table $1 . \mathrm{IC}_{50} \pm \mathrm{SD}$ of strongly and very strongly active compounds $(\mu \mathrm{M})$. FKd showing a $\mathrm{IC}_{50} \leq 10 \mu \mathrm{M}$ are in pale grey and those showing a IC $50 \leq 5 \mu \mathrm{M}$ are in dark grey. Results are the mean $\pm \mathrm{SD}$ from three independent experiments.

\begin{tabular}{|c|c|c|c|c|c|c|c|c|c|c|}
\hline FKd & $\mathrm{HuH7}$ & $\mathrm{CaCo}-2$ & MDA-MB-231 & HCT116 & PC3 & NCI-H727 & $\mathrm{HaCaT}$ & MCF-7 & $\mathrm{RL}$ & Fibro \\
\hline Rosco & $15.4 \pm 7.4$ & $12.9 \pm 5.5$ & $16.8 \pm 7.9$ & $8 \pm 4.1$ & $16.5 \pm 7.5$ & $>20$ & $16.7 \pm 8.3$ & $10.2 \pm 1.3$ & $0.9 \pm 1.4$ & $>20$ \\
\hline Pi-103 & $>20$ & $2 \pm 0.9$ & $>20$ & $3.9 \pm 0.4$ & $7.6 \pm 1.3$ & $>20$ & $3.5 \pm 0.5$ & $13.3 \pm 3.5$ & $2.9 \pm 0.9$ & $>20$ \\
\hline 2 & $15.9 \pm 1.1$ & $9.9 \pm 2.5$ & $16.3 \pm 0.2$ & $7.5 \pm 0.9$ & $9.1 \pm 1.5$ & $11.3 \pm 3.9$ & $13.6 \pm 2.4$ & $15.5 \pm 2.7$ & $8.2 \pm 0.6$ & $>20$ \\
\hline 5 & $>20$ & $9.2 \pm 0.7$ & $>20$ & $12.4 \pm 4$ & $13.2 \pm 0.1$ & $>20$ & $>20$ & $8.8 \pm 0.7$ & $5.4 \pm 3.2$ & $>20$ \\
\hline 8 & $15 \pm 1.5$ & $11.2 \pm 2$ & $13.2 \pm 0.8$ & $7.7 \pm 0.6$ & $7.3 \pm 0.1$ & $14.8 \pm 1.2$ & $10.4 \pm 0.8$ & $10.3 \pm 0.7$ & $9 \pm 2$ & $>20$ \\
\hline 9 & $>20$ & $10 \pm 0.5$ & $>20$ & $9.2 \pm 0.8$ & $9.6 \pm 0.7$ & $11 \pm 0.5$ & $10.9 \pm 1.5$ & $10.5 \pm 1.9$ & $10.1 \pm 0.6$ & $>20$ \\
\hline 10 & $16.6 \pm 2.2$ & $9.6 \pm 2.4$ & $>20$ & $10 \pm 1.4$ & $8.7 \pm 0.6$ & $9 \pm 1.9$ & $10.5 \pm 0.4$ & $15.9 \pm 1.1$ & $8.9 \pm 1.5$ & $>20$ \\
\hline 12 & $15.5 \pm 1$ & $5.8 \pm 1$ & $12.9 \pm 1.2$ & $6.9 \pm 0.7$ & $5.1 \pm 0.4$ & $11.4 \pm 1.7$ & $7.2 \pm 0.3$ & $9.4 \pm 1.9$ & $6.9 \pm 0.3$ & $>20$ \\
\hline 13 & $12.7 \pm 1.7$ & $5.7 \pm 1.6$ & $8.2 \pm 0.5$ & $5.4 \pm 0.5$ & $5.8 \pm 0.2$ & $6 \pm 1.3$ & $7.6 \pm 0.5$ & $7.5 \pm 1$ & $6.5 \pm 1.3$ & $>20$ \\
\hline 14 & $13.9 \pm 1$ & $6.8 \pm 0.7$ & $11.1 \pm 0.6$ & $6.2 \pm 0.4$ & $7.1 \pm 0.3$ & $11.3 \pm 1.7$ & $9 \pm 0.4$ & $9.5 \pm 1.2$ & $8.3 \pm 2.2$ & $>20$ \\
\hline 15 & $14.6 \pm 0.8$ & $5.5 \pm 0.3$ & $10.7 \pm 0.9$ & $6.2 \pm 1$ & $5.5 \pm 0.4$ & $5.5 \pm 2.1$ & $7.6 \pm 0.6$ & $7.7 \pm 1.2$ & $6.4 \pm 1$ & $>20$ \\
\hline 18 & $4.9 \pm 1.3$ & $2.6 \pm 0.3$ & $3.3 \pm 0.1$ & $2.7 \pm 0.3$ & $2.5 \pm 0.3$ & $4.1 \pm 0.2$ & $2.8 \pm 0.4$ & $5 \pm 0.6$ & $3.4 \pm 0.3$ & $7.3 \pm 0.7$ \\
\hline 19 & $8.9 \pm 0.8$ & $3.9 \pm 0.4$ & $8.7 \pm 0.8$ & $4.3 \pm 0.4$ & $3.1 \pm 0.2$ & $8.2 \pm 3.1$ & $5.3 \pm 0.5$ & $9.4 \pm 1.4$ & $5.9 \pm 0.7$ & $>20$ \\
\hline 20 & $9.8 \pm 3.2$ & $4.5 \pm 0.5$ & $13 \pm 2.4$ & $4.2 \pm 0.05$ & $8.1 \pm 0.4$ & $4 \pm 3$ & $8.7 \pm 0.6$ & $8.9 \pm 1.1$ & $9 \pm 2$ & $8.2 \pm 0.9$ \\
\hline 21 & $14.1 \pm 1.8$ & $8.8 \pm 2.1$ & $9.9 \pm 0.1$ & $6.8 \pm 0.5$ & $7.6 \pm 0.1$ & $8.7 \pm 1.3$ & $7.7 \pm 0.2$ & $9.3 \pm 0.6$ & $8.3 \pm 0.9$ & $>20$ \\
\hline
\end{tabular}

Compounds $2, \mathbf{5}, \mathbf{8 - 1 0}, \mathbf{1 2}-15,18-21$ revealed a strong activity against five to nine cancer cell lines $\left(\mathrm{IC}_{50}<20 \mu \mathrm{M}\right)$. Compound 18 exhibited the strongest activity $\left(\mathrm{IC}_{50}\right.$ ranging from 2.5 to 5.0 $\mu \mathrm{M})$ followed by compound 19 ( $\mathrm{IC}_{50}$ ranging from 3.1 to 9.4 $\mu \mathrm{M}), 20,13$ and 15 ( $\mathrm{IC}_{50}$ ranging respectively from 4.0 to $13 \mu \mathrm{M}$, from 5.4 to $12.7 \mu \mathrm{M}$ and from 5.5 to $14.6 \mu \mathrm{M}$ ). Compounds 1, 3, $4,6,7,11,16,17$ and 22 revealed no or weak activities $\left(\mathrm{IC}_{50}>\right.$ $20 \mu \mathrm{M})$ and were excluded of the end of this study. Although the majority of FKd exhibited no or weak activity against healthy cells, compounds $\mathbf{1 8}$ and $\mathbf{2 0}$ also revealed activity against fibroblasts $\left(\mathrm{IC}_{50}\right.$ of 7.3 and $8.2 \mu \mathrm{M}$, respectively). Only FKd with strong and very strong activities were kept for further investigations, as well as one inactive compound (4) as negative control.

Compounds of the second series with a trimethoxy A-ring (1122) exhibited higher cytotoxicity than those of the first series (110). As shown in figure 3 , the percentage of interesting $\mathrm{FKd}\left(\mathrm{IC}_{50}\right.$ $<20 \mu \mathrm{M})$ was higher for the second series $(67 \%)$ than for the first series $(38 \%)$, and the highly active $\mathrm{FKd}\left(\mathrm{IC}_{50} \leq 5 \mu \mathrm{M}\right)$ were only present in the second series (13\%). Moreover, when comparing the two compounds with the same B-ring, the one belonging to the second series was always more active than the one belonging to the first series. For example with the 3-methoxy B ring, compound $\mathbf{8}$ of the first series was more active on each cancer cell line than compound $\mathbf{1 9}$ of the second. Concerning the cytotoxic activities depending of the cancer cell lines, compounds of the first series exhibited weak cytotoxicities against $\mathrm{HuH}$, and MDA-MB-231 cell lines. Both series exhibited weak cytotoxicities against normal fibroblasts which is interesting in terms of safety profile in the drug development goal.

\subsubsection{Selectivity index (SI).}

For each interesting FKd $\left(\mathrm{IC}_{50}<20 \mu \mathrm{M}\right)$ and each cancer cell line, SI values were calculated according to the following formula: $\frac{\mathrm{IC}_{50} \text { fibroblasts }}{\mathrm{IC}_{50} \text { cancercells }}$ (Table 2$){ }^{42}$ As the SI demonstrates the contrast of a compound's activity between cancer cells and normal fibroblastic cells, the greater the SI value is, the more selective it is for cancer cells. An SI value of less than 2 indicated general toxicity of the compound. ${ }^{43}$ In table 2 , are depicted in grey the selective compounds, i.e. compounds with an SI value superior to 2 . 
$\mathrm{IC}_{50}$ of $\mathrm{FKd}$ on fibroblats were determined precisely when they were inferior to $50 \mu \mathrm{M}$. Thus, the determination of SI were done by taking an $\mathrm{IC}_{50}$ on fibroblasts of $50 \mu \mathrm{M}$ and by added a superior sign when the precise $\mathrm{IC}_{50}$ were not known.

Even if the percentage of selective FKd was the same in the two series $(82 \%)$, the second series only exhibited high selective FKd (SI $\geq 10$, figure 4). Moreover the average SI was higher for the second series (4.7) than for the first (3.2). Compounds of the first series were globally unselective for $\mathrm{HuH} 7$ and MDA-MB-231 cell lines. Compound 19 showed the higher SI (16.1) and the higher average SI (8.4) for cancer cells compared to normal fibroblastic cells. Compounds $\mathbf{1 2}$ and 14-15 showed an average SI for cancer cells superior to 5 (5.9, 6.6 and 6.7 , respectively). Compounds 20 showed the lower average SI (1.2) followed by compound 18 (2.1), and the natural FKB 2 (2.4). The FKd 20 and 18 with their strong activities on healthy cells and their nonselectivities for cancer cells were considered as not interesting in term of therapeutic development and were so removed for the next experiments of our study.

Table 2. Selectivity indices of interesting compounds ( $\mathrm{IC}_{50}<20 \mu \mathrm{M}$ ). SI $>1$ if compounds are more selective for cancer cells than fibroblasts, SI $<1$ if compounds are more selective for fibroblasts than cancer cells, and SI $=1$ if there is similar effect of the compound on cancer cells and fibroblasts. FKd showing a SI $>2$ are in pale grey and those showing a SI $>10$ are in dark grey. IC $_{50}$ of FKd on fibroblasts weren't calculated precisely when they were superior to $50 \mu \mathrm{M}$. Thus, the determination of SI were done by taking an $\mathrm{IC}_{50}$ on fibroblasts of $50 \mu \mathrm{M}$ and by added a superior sign when the precise $\mathrm{IC}_{50}$ were not known.

\begin{tabular}{|c|c|c|c|c|c|c|c|c|c|}
\hline FKd & $\mathrm{HuH7}$ & $\mathrm{CaCo}-2$ & MDA-MD-231 & HCT116 & PC3 & NCI-H727 & $\mathrm{HaCaT}$ & $\mathrm{RL}$ & MCF-7 \\
\hline Rosco & 6.4 & 7.6 & 5.8 & 12.2 & 5.9 & - & 5.9 & 108.6 & 9.7 \\
\hline Pi-103 & - & $>12.5$ & - & $>6.4$ & $>3.3$ & - & $>7.1$ & $>8.6$ & $>1.9$ \\
\hline 2 & 1.7 & 2.7 & 1.6 & 3.5 & 2.9 & 2.3 & 1.9 & 3.2 & 1.7 \\
\hline 5 & - & $>5.4$ & - & $>4$ & $>3.8$ & - & - & $>5.4$ & $>5.7$ \\
\hline 8 & 1.8 & 2.4 & 2 & 3.5 & 3.7 & 1.8 & 2.6 & 3 & 2.6 \\
\hline 9 & - & 3.6 & - & 4 & 3.8 & 3.3 & 3.3 & 3.6 & 3.5 \\
\hline 10 & 2.2 & 3.8 & - & 3.6 & 4.1 & 4 & 3.4 & 4.1 & 2.3 \\
\hline 12 & $>3.2$ & $>8.6$ & $>3.9$ & $>7.2$ & $>9.8$ & $>4.4$ & $>6.9$ & $>7.2$ & $>5.3$ \\
\hline 13 & 2.2 & 4.9 & 3.4 & 5.1 & 4.8 & 4.6 & 3.6 & 3.8 & 3.7 \\
\hline 14 & $>3.6$ & $>7.4$ & $>4.5$ & $>8.1$ & $>7$ & $>4.4$ & $>5.6$ & $>6$ & $>5.3$ \\
\hline 15 & $>3.4$ & $>9.1$ & $>4.7$ & $>8.1$ & $>9.1$ & $>9.1$ & $>6.6$ & $>7.8$ & $>6.5$ \\
\hline 18 & 1.5 & 2.8 & 2.2 & 2.7 & 2.9 & 1.8 & 2.6 & 2.1 & 1.5 \\
\hline 19 & $>5.6$ & $>12.8$ & $>5.7$ & $>11.6$ & $>16.1$ & $>6.1$ & $>9.4$ & $>8.5$ & $>5.3$ \\
\hline 20 & 0.8 & 1.8 & 0.6 & 2 & 1 & 2.1 & 0.9 & 0.9 & 0.9 \\
\hline 21 & 2.3 & 3.6 & 3.2 & 4.7 & 4.2 & 3.7 & 4.1 & 3.8 & 3.4 \\
\hline
\end{tabular}

\subsubsection{Cellular death induced by FKd.}

Apoptosis induced by FKd was studied at the concentration of $2 \times \mathrm{IC}_{50}$ of each $\mathrm{FKd}$ on four cancer cell lines: two p53 wild-type (HCT116 and MCF-7) and two p53 mutant-type (PC3 and MDAMB-231). Apoptosis was evaluated by the incorporation of two markers, due to the increasing cell permeability during cellular death. YoPro was incorporated during early apoptosis and propidium iodide (PI) during late apoptosis. Cells were then costained with Hoescht fluorescent dye and the percentages of cell death were calculated according to the following formula: number of specific labelled cells(PI or YoProdye)

$$
\text { number of cells(Hoechst dye) }
$$

Figure 5 gives the fold inductions of early (pale grey) and late (dark grey) apoptosis for the interesting FKd after 24h (left histogram) and $48 \mathrm{~h}$ (right histogram) of treatments on the remaining cells. All the interesting FKd induced an increase in cell death but with variable kinetics.

Indeed for HCT116 and PC3 cells, the induction of cellular death was significant after $48 \mathrm{~h}$ of treatment whilst for MDA-MB-231 and MCF-7 cells this was significant only after $24 \mathrm{~h}$. As negative control, inactive compound (4) showed no significant upregulation of cellular death. For each interesting FKd, the fold induction of early apoptosis was higher than the fold induction of late apoptosis, except for the MDA-MB-231 cell line for which the inverse phenomenon was observed. For HCT116 and MCF-7, FKd of the first series had a higher average fold induction of cellular death than FKd of the second series. However, FKd of the second series had a higher average fold induction of cellular death for PC3 and MDA-MB-231 cells.
Apoptosis is regulated by the cleavage of the caspase- 3 protein (CASP3). The CASP3 antibody is a universal marker for apoptosis by detecting cleaved CASP3. To confirm the upregulation of apoptosis by $\mathrm{FKd}$, cancer cells were labeled with Hoechst fluorescent dye and the CASP3 antibody except for the MCF-7 cell line that is CASP3 deficient. ${ }^{44}$ The results found with the CASP3 assays (Figure 6) confirmed the results found with YoPro/PI test.

\subsection{FKd mechanisms of action.}

The FKd mechanisms of action on cancer cells were investigated using fluorescence and immunofluorescence. First, elucidation of the targeted cell cycle phases was done by measuring the percentage of cells in the $S$ and $M$ phase on adherent cancer cell lines. Then, the induction of cellular death as well as the levels of two cell cycle proteins (p21 and cyclin B1) were investigated on four cancer cell lines MDA-MB-231, MCF7, HCT116 and PC3, selected according to their different p53 and Akt/mTor status. All the FKd were tested at a concentration of $\mathrm{IC}_{50}$ or/and $2 \times \mathrm{IC}_{50}$ in order to observed the effect of $\mathrm{FKd}$ without killing all the cells to obtain significant results.

\subsubsection{Mitotic index (MI) or percentage of cells in the M phase.}

During mitosis, the DNA condensation process is regulated by the phosphorylation of histone H3, a DNA associated nuclear protein. The phosphor-histone $\mathrm{H} 3$ antibody (PHH3) is a universal marker for mitosis by detecting the phosphorylated histone. Cancer cells were labelled with Hoechst fluorescent dye and the PHH3 antibody and the MI values were calculated according to the following formula: 
number of specific labelled cells(fluorophore-coupled PHH3 antibody) number of cells(Hoechst dye)

An increase in MI compared to the control meant that cells entered into mitosis but were blocked before the end of the division. Therefore, compounds' action occurred during the $\mathrm{M}$ phase before the $\mathrm{M}$ checkpoint. A decrease of MI compared to the control meant that the cells did not enter into the $\mathrm{M}$ phase and consequently the compounds' action occurred before the beginning of the $\mathrm{M}$ phase.
Table 3 summarizes the MI for each interesting FKd at two different concentrations $\left(\mathrm{C}_{1} \approx \mathrm{IC}_{50}=10 \mu \mathrm{M} ; \mathrm{C}_{2} \approx 2 \times \mathrm{IC}_{50}=25\right.$ $\mu \mathrm{M})$. Figure $2 \mathrm{c}$ gives the example of roscovitine and compound 19 treatments on HCT116 cell line compared to DMSO treatment (control). All FKd treatments led to an increase of MI for CaCo2, PC3 (except compound 2) and MDA-MB-231 cell lines. For NCI-H727 and HCT116 (except compound 9) cell lines, all FKd treatments led to a decrease of MI. For the $\mathrm{HuH7}$ and $\mathrm{HaCaT}$ cell lines, second series FKd treatments led to an increase of MI.

Table 3. Mitotic index (MI) and percentage of proliferating cells $(\% \mathrm{~S})$ after treatment by strongly and very strongly active compounds at two concentrations $\left(\mathrm{C}_{1}\right.$ $\approx \mathrm{IC}_{50}=10 \mu \mathrm{M}$ and $\mathrm{C}_{2} \approx 2 \times \mathrm{IC}_{50}=25 \mu \mathrm{M}$ ) and observed variations $(\Delta)$ compared to control (DMSO at final concentration for $\mathrm{FKd}$ ). " + " if $\mathrm{MI}$ or $\% \mathrm{~S}$ is higher after compound treatment than control, "-" if MI or \%S is lower after compound treatment than control and "0" reflects no difference between compound and control treatments

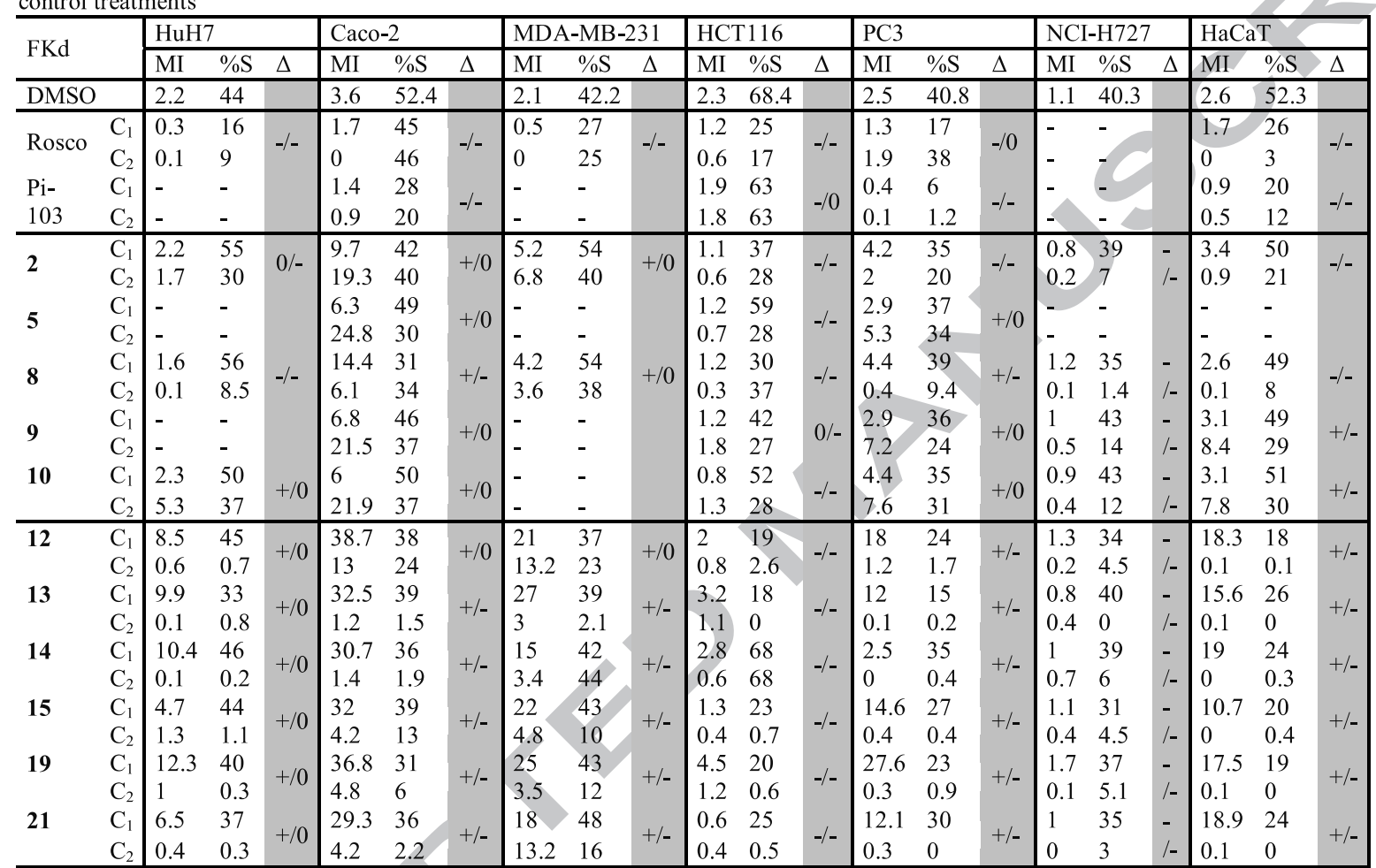

Not determined for MCF-7 and RL cell lines

\subsubsection{Percentage of cells in the $S$ phase.}

Cells were grown with bromodeoxyuridine (BrdU), a thymidine analogue that is incorporated in cells during DNA synthesis (S phase). Cancer cells were labelled with Hoechst fluorescent dye and BrdU antibody and the percentages of cells in the $\mathrm{S}$ phase were calculated according to the following formula:

$\underline{\text { number of specific labelled cells(fluorophore-coupled BrdU antibody) }}$

number of cells(Hoechst dye)

An increase of the percentage of cells in the S phase compared to the control indicated that cells entered into DNA synthesis but were blocked before the end of the replication. Therefore, the compounds' action occurred during the S phase before the G2/M checkpoint. A decrease of the percentage of cells in the $\mathrm{S}$ phase compared to control indicated that cells did not enter into the $\mathrm{S}$ phase indicating that the compounds' action occurred before the G1/S checkpoint.
Table 3 summarizes the percentage of cells in the DNA synthesis phase for each interesting $\mathrm{FKd}$ at two different concentrations $\left(\mathrm{C}_{1} \approx \mathrm{IC}_{50}=10 \mu \mathrm{M} ; \mathrm{C}_{2} \approx 2 \times \mathrm{IC}_{50}=25 \mu \mathrm{M}\right)$. Figure $2 \mathrm{~d}$ gives the example of roscovitine and compound 19 treatments on the HCT116 cell line compared to DMSO treatment (control).

No interesting compound led to an increase of the percentage of cells in the $\mathrm{S}$ phase. All interesting FKd led to a decrease of the number of cells in DNA synthesis for the HCT116, HaCaT and NCI-H727 cell lines. The percentage of cells in the DNA synthesis phase was unchanged for compounds of the second series for $\mathrm{HuH} 7$ but was decreased for other cancer cell lines.

\subsubsection{Targeted cell cycle phase.}

To elucidate the phase of the cell cycle targeted by the FKd, we compared the percentages of cells in the $S$ and $M$ phases between control and compounds after $48 \mathrm{~h}$-treatments. Table 3 summarizes all the observed variations (column $\Delta$ ). Figure $2 \mathrm{e}$ gives the determination keys based on these variations through 
the example of roscovitine and compound 19 treatments on the HCT116 cell line compared to DMSO treatment (control) and table 4 summarizes the phases of the cell cycle targeted by the FKd.

All interesting FKd had a blocking action during mitosis for CaCo-2, MDA-MD-231, PC3 (except compound 2), HaCaT and $\mathrm{HuH} 7$ (except compounds $\mathbf{2}$ and $\mathbf{8}$ ) cell lines. All interesting FKd had a blocking action on the G1/S checkpoint for HCT116 and NCI-H727.

Table 4. Targeted cell cycle phases. Depending on the variation of the mitotic index and the percentage of cells after compound treatments compared to control (table 3 ), according to figure $2 \mathrm{e}$

\begin{tabular}{|c|c|c|c|c|c|c|c|}
\hline$\frac{\vec{v}}{I}$ & $\underset{\Xi}{\Xi}$ & 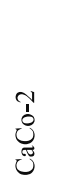 & 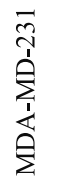 & 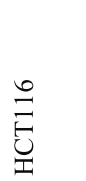 & $\underline{U}$ & 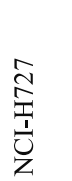 & 䚄 \\
\hline Rosco & G1/S & $\mathrm{G} 1 / \mathrm{S}$ & G1/S & G1/S & $\mathrm{G} 2 / \mathrm{M}$ & - & G1/S \\
\hline Pi-103 & - & $\mathrm{G} 1 / \mathrm{S}$ & - & $\mathrm{G} 2 / \mathrm{M}$ & $\mathrm{G} 1 / \mathrm{S}$ & - & $\mathrm{G} 1 / \mathrm{S}$ \\
\hline 2 & $\mathrm{G} 1 / \mathrm{S}$ & $\mathrm{M}$ & $\mathrm{M}$ & $\mathrm{G} 1 / \mathrm{S}$ & $\mathrm{G} 1 / \mathrm{S}$ & $\mathrm{G} 1 / \mathrm{S}$ & $\mathrm{G} 1 / \mathrm{S}$ \\
\hline 5 & - & M & - & $\mathrm{G} 1 / \mathrm{S}$ & M & - & - \\
\hline 8 & $\mathrm{G} 1 / \mathrm{S}$ & $\mathrm{M}$ & $\mathrm{M}$ & $\mathrm{G} 1 / \mathrm{S}$ & M & $\mathrm{G} 1 / \mathrm{S}$ & $\mathrm{G} 1 / \mathrm{S}$ \\
\hline 9 & - & M & - & $\mathrm{G} 1 / \mathrm{S}$ & M & $\mathrm{G} 1 / \mathrm{S}$ & $\mathrm{M}$ \\
\hline 10 & M & M & - & $\mathrm{G} 1 / \mathrm{S}$ & M & $\mathrm{G} 1 / \mathrm{S}$ & $\mathrm{M}$ \\
\hline 12 & - & $M$ & $\mathrm{M}$ & $\mathrm{G} 1 / \mathrm{S}$ & $\mathrm{M}$ & G1/S & $\mathrm{M}$ \\
\hline 13 & M & M & M & $\mathrm{G} 1 / \mathrm{S}$ & M & $\mathrm{G} 1 / \mathrm{S}$ & M \\
\hline 14 & M & M & M & $\mathrm{G} 1 / \mathrm{S}$ & M & $\mathrm{G} 1 / \mathrm{S}$ & M \\
\hline 15 & M & M & M & $\mathrm{G} 1 / \mathrm{S}$ & M & $\mathrm{G} 1 / \mathrm{S}$ & $\mathrm{M}$ \\
\hline 19 & M & M & M & $\mathrm{G} 1 / \mathrm{S}$ & M & $\mathrm{G} 1 / \mathrm{S}$ & $\mathrm{M}$ \\
\hline 21 & M & M & $\mathrm{M}$ & $\mathrm{G} 1 / \mathrm{S}$ & $\mathrm{M}$ & $\mathrm{G} 1 / \mathrm{S}$ & $\mathrm{M}$ \\
\hline
\end{tabular}

Not determined for MCF-7 and RL cell lines

3.3.4. FKd increased the level of p 21 in p53 wildtype cancer cells.

The effects of exposure to $\mathrm{FKd}$ on the cell cycle regulatory molecule p21 were then examined after $48 \mathrm{~h}$ of treatment at the concentration of $2 \times \mathrm{IC}_{50}$ by $\mathrm{p} 21$ antibody labelling. The percentages of $\mathrm{p} 21$ positive cells were calculated according to the following formula:

$$
\frac{\text { number of specific labelled cells(fluorophore-coupled p21antibody) }}{\text { number of cells(Hoechst dye) }} \times
$$

The p21 protein was not detected in the p53-mutant type cell line (data not shown) but was detected in the p53 wild-type HCT116 and MCF-7 cancer cell lines (Figure 7). Treatment of p53 wild-type cancer cells with interesting FKd induced an upregulation of $\mathrm{p} 21$ protein expression with a weak effect of the compounds of the first series on MCF-7 cells, and inactive compound (4) showed no significant up-regulation of $\mathrm{p} 21$ protein level. Interesting FKd had more effects on the $\mathrm{p} 21$ protein on the HCT116 cancer cell line than MCF-7 cells (fold inductions higher for HCT116 than MCF-7) but, this could be explained by the kinetics. Indeed, the induction of apoptosis on MCF-7 by
FKd was visible after 24h-treatment; consequently, the effect of FKd on p21 should be approximately $24 \mathrm{~h}$ after treatment. After $48 \mathrm{~h}$ of treatment, which was the observation time, the level of p21 positive cells could already be decreasing and therefore the fold inductions of $\mathrm{p} 21$ could already be decreasing too.

\subsubsection{Level of cyclin B1 increased by FKd.}

The effects of exposure to FKd on the cell cycle regulatory molecule cyclin B1 were examined by a cyclin B1 antibody labelling after 18h- and 48h-treatments (Figure 8). The percentages of cyclin B1 positive cells were calculated according to the following formula:

$$
\frac{\text { number of specific labelled cells(fluorophore-coupled cyclin Blantibody) }}{\text { number of cells(Hoechst dye) }} \times
$$

Up-regulations of cyclin $\mathrm{B} 1$ were detected for the fourth tested cell lines: HCT116, MCF-7, MDA-MB-231 and PC3, still with variable kinetics and with a weak effect on MCF-7 for FKd of the first series. Indeed, for the HCT116 and PC3 cells, the percentages of cyclin $\mathrm{B} 1$ cells were significant after $48 \mathrm{~h}$ of treatment unlike MDA-MB-231 and MCF-7 cells, for which the percentages of cyclin B1 cells were significant after only $18 \mathrm{~h}-$ treatment. Simultaneously inactive compound (4) showed no significant increasing of the percentage of cyclin B1 cells.

\section{Discussion}

Twenty-two FKd were synthesized and evaluated in vitro for their effects against nine cancer cell lines and normal human fibroblasts. The targeted cell cycle phases as well as the FKd effects on the induction of cell death and cell cycle proteins levels were investigated for the strongly and the very strongly active FKd. Firstly, an analysis of the activities and selectivities was done to highlight the therapeutic improvement by some FKd compared to natural FKA and FKB. Second, an analysis of the mechanisms of action was conducted to improve the comprehension of FKd effects on different types of cancer cells. Finally, a structure-activity relationship analysis was performed to understand the structural requirements for optimum activity.

\subsection{Therapeutic improvements.}

On one hand, FKA showed weak activity against cancer cell lines. On the other hand, FKB was active against all the tested cancer cell lines and particularly against CaCo-2, HCT116, PC3 and $\mathrm{RL}$ with $\mathrm{IC}_{50}<10 \mu \mathrm{M}$. These results were consistent with previous published data. Moreover, we were able to highlight the non-selectivity of FKB for cancer cells.

In previous studies, compounds $3,5,7-9,11,13,17,18,20$ and $\mathbf{2 2}$ were included in structure-activity relationship studies related to anti-cancer activities. Consistent with our results, compounds 3, 5, 7-9, 11 (except on HepG2 cancer cell line), 17 and $\mathbf{2 2}$ showed weak activities, ${ }^{7,28,32,34,45,46}$ while compounds 13, 18 and 20 showed strong activities. ${ }^{34}$ In addition, therapeutic improvements were achieved with FKd of the second series which were indeed more active and also more selective against cancer cells compared to natural FKA and FKB. Compound 19 revealed the best compromise between strong activity and high selectivity, followed by compound 15 . Other $\mathrm{FKd}$, notably compound 18 and $\mathbf{2 0}$, were very cytotoxic but presented very low selectivity indices. No further investigation has been conducted on this compound because of its high cytotoxicity against healthy cells making it unattractive for drug development.

\subsection{Mechanisms of action.}


FKd could target several molecular pathways and we showed in this study that FKd could either block the cell cycle in G1/S or in mitosis. This feature is found for all FKd except for FKB. Therefore FKd have different mechanisms of action depending on the cell type, but not of their molecular structure. Thus, FKd blocked the cell cycle in G1/S or in mitosis according to the p53 status of the cells. For p53 wild-type cancer cells (HCT116 and MCF-7), FKd activated the p53-p21 ${ }^{\text {Cip1 }}$ pathway and induced a cell cycle arrest in G1/S followed by apoptosis. ${ }^{8}$ For the p53 mutant-type cancer cell lines (MDA-MB-231 and PC3), FKd induced a cell cycle arrest during mitosis leading to cytotoxic activity with cellular death. Tang \& al, in 2008 highlighted these two mechanisms of action on different cancer cell lines. Indeed they showed that FKA induced a cell cycle arrest in G1/S on p53 wild-type cancer cell lines (RT4) and in G2/M on p53 mutanttype cancer cell lines (T24, UMUC3, TCCSUP, 5637, HT1376 and HT1197). ${ }^{9}$ Our method used to determine the targeted cell cycle phases was different and more exploratory than the previous studies and this can explain the different results found, in particular our possibility to differentiate arrests in $G 2 / M$ and $\mathrm{M}$ phases. In the same way, previous studies showed that FKB induced a G2/M cell cycle arrest on p53 mutant-type cell lines $^{8,14,15,18,23}$ and induced a G2/M cell cycle arrest also on p53 wild-type cancer cells, notably a $\mathrm{G} 2 / \mathrm{M}$ cycle arrest on p53 wildtype HCT116 cancer cells, but the used concentrations were very high: $25\left(\approx 3 \times \mathrm{IC}_{50}\right)$ and $50 \mu \mathrm{M}\left(\approx 6 \times \mathrm{IC}_{50}\right)$, leading to kill too many cells to obtain significant results., ${ }^{9}, 17$ These results supported by ours confirmed that FKB is not specific to one target and can act differently depending on cancer cells, concentrations or time of exposure. The FKd, especially those of the second series, were more specific to one target and induced G1/S arrest on the p53 wild-type cancer cell lines and $\mathrm{M}$ arrest on the p53 mutant-type; except for the p53 mutant-type NCI-H727 cancer cell line on which FKd induced a G1/S cell cycle arrest. This can be explained by a partial remaining activity of the truncated p53 protein. ${ }^{47}$

FKd had variable kinetics of action according to the Akt/mTor status of the cells. ${ }^{48,49}$ For the cells with an over-expression of this signaling pathway (HCT116 and PC3), FKd were active after $48 \mathrm{~h}$ of treatment. For the cells with a normal expression of this signaling pathway (MDA-MB-231 and MCF-7), FKd were active only after $24 \mathrm{~h}$ of treatment. The difference of intensity observed for the induction of cyclin B1 and p21 can probably be explained by this difference of kinetics between the cancer cell lines and between the FKd themselves.

The G1/S arrest for p53-wild type cancer cells was mediated by the up-regulation of cyclin $\mathrm{B} 1$ and $\mathrm{p} 21$ proteins. $\mathrm{p} 21$ is known to be a nucleus CDK inhibitor, responsible for cell cycle arrest in $\mathrm{G} 1 / \mathrm{S}$. The up-regulation of the Akt/mTor pathway can interfere with the inhibitory activity of $\mathrm{p} 21$ by phosphorylating and transporting it into the cytoplasm. ${ }^{50}$ When we compared the p53wild type cancer cell lines, HCT116 and MCF-7, we observed that the fold induction and the percentage of $\mathrm{p} 21$ positive cells as well as the delay of effects were higher in HCT116 cells and might be explained by the up-regulation of the Akt/mTor pathway. The arrest during mitosis for p53-mutant type cancer cells was mediated by the up-regulation of cyclin B1. In a same way, up-regulation of Akt/mTor seems to delay the activities and decreases the sensitivities. Indeed, when we compared the p53mutant type cancer cell lines PC3 and MDA-MB-231, we observed that the fold induction and the percentage of $\mathrm{p} 21$ positive cells as well as the delay of effects were higher in MDAMB-231 cells up-regulating the Akt/mTor pathway.

\subsection{Structure-activity relationships.}

Two series of molecules with several pharmacomodulations on both aromatic rings were synthesized with among them the natural leads from kava roots: FKA 1 and FKB 2. All these molecules were compared with cytotoxic tests to determine the structural requirements for FKd to inhibit cell growth and to induce cellular death in cancer cells, leading to candidates for anticancer drug development. The summary of SAR is given in figure 9.

First of all, structure-activity relationships (SAR) were investigated by modification of the A-ring: a 2-hydroxy-4,6dimethoxy moiety for the first series and a 2,4,6-trimethoxy moiety for the second series. FKd of the second series were more active and more selective than those of the first series for each single B-ring, except for compound 20 that was less selective than compound 9 due to its toxicity against fibroblasts. The presence of a hydroxyl group on the ortho position on the A-ring caused the stabilization of FKd by the formation of a 6-atom ring due to an H-bond between the hydrogen of the hydroxyl and the oxygen of the ketone group. In the second series, there was no $\mathrm{H}$ bond stabilizing the FKd; structures were then more flexible. This feature could allow a better integration within the active site(s) targeted by FKd. In the literature, other modification increasing the flexibility of chalcones has been tried. Indeed, the double bond between the two rings $\mathrm{A}$ and $\mathrm{B}$ were removed leading to a drastic increase of the flexibility of the molecule but resulting in a significant decrease of the activity. ${ }^{51}$ It can be noted that FKd of the first series showed a greater diversity of targeted cell cycle phases. Indeed for one cancer cell line, targeted cell cycle phase was sometimes different between FKd of the first series. FKd of the first series may therefore act on more than one molecular target, sometimes specifically for each cancer cell line.

Secondly, SAR were investigated by substituent modification of the B-ring in the ortho, meta and para positions. Different characteristics of functional groups can affect FKd activities such as steric properties, electronegativity and H-bond acceptor or donor. The most bulky groups (carboxyl and dimethylamine) led to complete inactivity, showing that steric hindrance plays a key role in FKd activity that was generated by the smallest substituents. In the first series, substitution of the para position was unfavorable, and only compound $\mathbf{5}$ with a small atom of fluorine was strongly active in this position. The substitution of the methoxy group or thiomethoxy group in the ortho position (9 and 10) enhanced the activity of this series. No substituent (2) or shifting the methoxy group to the meta position (8) allowed activity of these compounds but introduced an unspecificity of these compounds for the target. Thus, they can act differently depending on cancer cells, concentration and times of exposure. For the second series the SAR indicated that no substitution (12) or presence in the para position of chlorine (13), bromine (14) and fluorine (15) enhanced cytotoxicity against cancer cell lines. Introduction of a thiomethoxy group in the ortho position also had a positive effect whereas a methoxy group in the same position (20) generated toxicity against fibroblasts. The best activities and selectivities were observed when a methoxy group was placed in the meta position (19). In this second series, the position of the methoxy group on the B-ring played a key role to allow cytotoxicity: meta position of the methoxy group showed the best activities and selectivities, closely followed by the ortho position (20) but with bad selectivity and cytotoxicity on normal fibroblast, whilst the para position of the methoxy group led to a weak cytotoxic activity even if it was as in the natural flavokawain in plants. The influence of the substitution of the B ring in FKd was dependent on the series because different patterns were observed in both series. Indeed, changes in the A 
ring could generated different propenone chain orientations thus shifting the position of ring $\mathrm{B}$.

\section{Conclusion.}

In summary, we demonstrated that FKA showed weak cytotoxic activities against nine cancer cell lines compared to FKB which could be the most active cytotoxic compound of kava extract and may be responsible for kava-drinking population's protection against many cancers. A short and rapid synthesis by Claisen-Schmidt condensation allowed us to obtain 22 flavokawain derivatives. The study of their structure-activity relationships gave some valuable findings about the understanding of the structural requirements for optimum and selective cytotoxicity for this class of compounds. Thereby, compounds 12, 13, 14, 15, 19 and 21 possessing a 2,4,6trimethoxyphenyl A-ring and substituent 2- $\mathrm{SCH}_{3}, 3-\mathrm{OCH}_{3}$, 4halogens or 4-H on ring $\mathrm{B}$ showed potent and selective activities against all cancer cell lines. FKd induced G1/S arrest on p53 wild-type cancer cell lines by activation of the p53-p21 $1^{\text {Cip } 1}$ pathway followed by apoptosis, and induced $\mathrm{M}$ arrest on p53 mutant-type. FKd had also variable kinetics of action according to the Akt/mTor status, demonstrating that the intracellular signaling pathway PI3K/AKT/mTOR could be involved in their mechanism of action. Finally, we showed that several FKd and especially compound 19 which is the most effective of the series, were more specific than natural flavokawains and could be good candidates as alternative drugs in resistant cancers. Based on this SAR study as well as literature data, improvement by pharmacomodulation can still be achieved. Notably, the modification of the meta substituent on the B-ring should be investigated.

However, these first results should be refined in vitro by cellular, molecular and biochemical approaches, and confirmed in vivo in a mouse xenograft model to know if there is no other primordial mechanism of action involved, for example as angiogenesis or cellular proliferation inhibitors. Moreover, an understanding of metabolic pathways (excretion or metabolism elimination; one or more active or inactive metabolites), potential interactions, and individual differences in metabolic rates allow the use of a drug in a safe and effective way. Further studies should also be conducted to better understand the chemosensitizer activity of constituents of kava on flavokawains, and notably the inhibition of P-glycoprotein (a multidrug resistance protein) by kavalactones ${ }^{52}$ that could explain kavadrinking population's protection against many cancers in the South Pacific Islands.

\section{Acknowledgments}

We would like to thank the ImPACcell platform of UMS Biosit for the cytotoxic tests as well as IRD of Noumea for hosting our research team in its premises. We would also thank the New Caledonia government and the Pacific funding for their financial supports.

\section{References and notes}

1. Henderson, B. E. et al. Cancer incidence in the islands of the Pacific. Natl. Cancer Inst. Monogr. 69, 73-81 (1985).

2. Steiner, G. G. The correlation between cancer incidence and kava consumption. Hawaii Med. J. 59, 420-422 (2000).

3. Tabudravu, J. N. \& Jaspars, M. Anticancer activities of constituents of kava (Piper methysticum). S. Pac. J. Nat. Appl. Sci. 23, 26-29 (2005).
4. Zi, X. L. \& Simoneau, A. R. Flavokawain A, a novel chalcone from kava extract, induces apoptosis in bladder cancer cells by involvement of Bax protein-dependent and mitochondria-dependent apoptotic pathway and suppresses tumor growth in mice. Cancer Res. 65, 3479-3486 (2005).

5. Cabrera, M. et al. Synthetic chalcones, flavanones, and flavones as antitumoral agents: Biological evaluation and structure-activity relationships. Bioorg. Med. Chem. 15, 33563367 (2007).

6. Juvale, K., Pape, V. F. S. \& Wiese, M. Investigation of chalcones and benzochalcones as inhibitors of breast cancer resistance protein. Bioorg. Med. Chem. 20, 346-355 (2012).

7. Mai, C. W., Yaeghoobi, M., Abd-Rahman, N., Kang, Y. B. \& Pichika, M. R. Chalcones with electron-withdrawing and electron-donating substituents: Anticancer activity against TRAIL resistant cancer cells, structure-activity relationship analysis and regulation of apoptotic proteins. Eur. J. Med. Chem. 77, 378-387 (2014).

8. Abu, N. et al. Flavokawain A Induces Apoptosis in MCF-7 and MDA-MB231 and Inhibits the Metastatic Process In Vitro. PLoS ONE 9, e105244 (2014).

9. Tang, Y., Simoneau, A. R., Xie, J., Shahandeh, B. \& Zi, X. Effects of the Kava Chalcone Flavokawain A Differ in Bladder Cancer Cells with Wild-type versus Mutant p53. Cancer Prev. Res. (Phila. Pa.) 1, 439-451 (2008).

10. Abu, N. et al. The flavokawains: uprising medicinal chalcones. Cancer Cell Int. 13, 102 (2013).

11. Abu, N. et al. In Vivo Anti-Tumor Effects of Flavokawain A in 4T1 Breast Cancer Cell-Challenged Mice. Anticancer Agents Med. Chem. 15, 905-915 (2015).

12. Li, X. et al. Kava Components Down-Regulate Expression of AR and AR Splice Variants and Reduce Growth in Patient-Derived Prostate Cancer Xenografts in Mice. Plos One 7, e31213 (2012).

13. Ji, T. et al. Flavokawain B, a kava chalcone, inhibits growth of human osteosarcoma cells through $\mathrm{G} 2 / \mathrm{M}$ cell cycle arrest and apoptosis. Mol. Cancer 12, (2013).

14. Lin, E. et al. Flavokawain B inhibits growth of human squamous carcinoma cells: Involvement of apoptosis and cell cycle dysregulation in vitro and in vivo. J. Nutr. Biochem. 23, 368-378 (2012).

15. An, J. et al. Flavokawain B induces apoptosis of nonsmall cell lung cancer $\mathrm{H} 460$ cells via Bax-initiated mitochondrial and JNK pathway. Biotechnol. Lett. 34, 1781-1788 (2012).

16. Eskander, R. N. et al. Flavokawain B, a novel, naturally occurring chalcone, exhibits robust apoptotic effects and induces $\mathrm{G} 2 / \mathrm{M}$ arrest of a uterine leiomyosarcoma cell line. J. Obstet. Gynaecol. Res. 38, 1086-1094 (2012).

17. Zhao, X. et al. Flavokawain B induces apoptosis of human oral adenoid cystic cancer ACC-2 cells via upregulation of Bim and down-regulation of Bcl-2 expression. Can. J. Physiol. Pharmacol. 89, 875-882 (2011).

18. Sakai, T. et al. Flavokawain B, a kava chalcone, induces apoptosis in synovial sarcoma cell lines. J. Orthop. Res. 30, 1045-1050 (2012).

19. Kuo, Y.-F. et al. Flavokawain B, a novel chalcone from Alpinia pricei Hayata with potent apoptotic activity: Involvement of ROS and GADD153 upstream of mitochondria-dependent apoptosis in HCT116 cells. Free Radic. Biol. Med. 49, 214-226 (2010).

20. Hseu, Y.-C. et al. The Chalcone Flavokawain B Induces G2/M Cell-Cycle Arrest and Apoptosis in Human Oral Carcinoma HSC-3 Cells through the Intracellular ROS Generation and Downregulation of the Akt/p38 MAPK Signaling Pathway. J. Agric. Food Chem. 60, 2385-2397 (2012). 
21. Tang, Y. et al. Flavokawain B, a kava chalcone, induces apoptosis via up-regulation of death-receptor 5 and Bim expression in androgen receptor negative, hormonal refractory prostate cancer cell lines and reduces tumor growth. Int. J. Cancer 127, 1758-1768 (2010).

22. Seo, Y. H. \& Park, S. Y. Synthesis of Flavokawain Analogues and their Anti-neoplastic Effects on Drug-resistant Cancer Cells Through Hsp90 Inhibition. Bull. Korean Chem. Soc. 35, 1154-1158 (2014).

23. Abu, N. et al. Flavokawain B induced cytotoxicity in two breast cancer cell lines, MCF-7 and MDA-MB231 and inhibited the metastatic potential of MDA-MB231 via the regulation of several tyrosine kinases In vitro. BMC Complement. Altern. Med. 16, (2016).

24. Tang, Y.-L. et al. Flavokawain B inhibits the growth of acute lymphoblastic leukemia cells via p53 and caspasedependent mechanisms. Leuk. Lymphoma 56, 2398-2407 (2015).

25. Orlikova, B. et al. Natural chalcones as dual inhibitors of HDACs and NF-?B. Oncol. Rep. 28, 797-805 (2012).

26. Phang, C.-W., Karsani, S. A., Sethi, G. \& Abd Malek, S. N. Flavokawain C Inhibits Cell Cycle and Promotes Apoptosis, Associated with Endoplasmic Reticulum Stress and Regulation of MAPKs and Akt Signaling Pathways in HCT 116 Human Colon Carcinoma Cells. PLOS ONE 11, e0148775 (2016).

27. Kwon, D.-J., Ju, S. M., Youn, G. S., Choi, S. Y. \& Park, J. Suppression of iNOS and COX-2 expression by flavokawain A via blockade of NF-kappa B and AP-1 activation in RAW 264.7 macrophages. Food Chem. Toxicol. 58, 479-486 (2013).

28. Srinivasan, B., Johnson, T. E., Lad, R. \& Xing, C. Structure-activity relationship studies of chalcone leading to 3 hydroxy-4,3',4',5'-tetramethoxychalcone and its analogues as potent nuclear factor $\mathrm{kappaB}$ inhibitors and their anticancer activities. J. Med. Chem. 52, 7228-7235 (2009).

29. Folmer, F. et al. Inhibition of TNF alpha-induced activation of nuclear factor kappa B by kava (Piper methysticum) derivatives. Biochem. Pharmacol. 71, 1206-1218 (2006).

30. Li, N., Liu, J.-H., Zhang, J. \& Yu, B.-Y. Comparative Evaluation of Cytotoxicity and Antioxidative Activity of 20 Flavonoids. J. Agric. Food Chem. 56, 3876-3883 (2008).

31. Srinivasan, B., Johnson, T. E. \& Xing, C. Chalconebased inhibitors against hypoxia-inducible factor 1 - Structure activity relationship studies. Bioorg. Med. Chem. Lett. 21, 555557 (2011).

32. Jeong, H.-J. et al. Flavokawains B and C, melanogenesis inhibitors, isolated from the root of Piper methysticum and synthesis of analogs. Bioorg. Med. Chem. Lett. 25, 799-802 (2015).

33. Chiaradia, L. D. et al. Synthesis and pharmacological activity of chalcones derived from 2,4,6-trimethoxyacetophenone in RAW 264.7 cells stimulated by LPS: Quantitative structureactivity relationships. Bioorg. Med. Chem. 16, 658-667 (2008).

34. Zhang, B. et al. Synthesis of Xanthohumol Analogues and Discovery of Potent Thioredoxin Reductase Inhibitor as Potential Anticancer Agent. J. Med. Chem. 58, 1795-1805 (2015).

35. Batt, D. G. et al. 2'-substituted chalcone derivatives as inhibitors of interleukin-1 biosynthesis. J. Med. Chem. 36, 1434 1442 (1993).
36. Kachadourian, R. et al. A Synthetic Chalcone as a Potent Inducer of Glutathione Biosynthesis. J. Med. Chem. 55, 1382-1388 (2012).

37. Kumar, V. et al. Novel Chalcone Derivatives as Potent Nrf2 Activators in Mice and Human Lung Epithelial Cells. $J$. Med. Chem. 54, 4147-4159 (2011).

38. Boeck, P. et al. Synthesis of chalcone analogues with increased antileishmanial activity. Bioorg. Med. Chem. 14, 15381545 (2006).

39. Detsi, A., Majdalani, M., Kontogiorgis, C. A., Hadjipavlou-Litina, D. \& Kefalas, P. Natural and synthetic 2'hydroxy-chacones and aurones: Synthesis, characterization and evalution of the antioxydant and soybean lipoxygenase inhibitory activity. Bioorg. Med. Chem. 8073-8085 (2009).

40. Neniškis, A. \& Stončius, S. Enantioselective Ring Opening of meso-Epoxides with Silicon Tetrachloride Catalyzed by Pyridine N-Oxides Fused with the Bicyclo[3.3.1]nonane Framework. Eur. J. Org. Chem. 2015, 6359-6369 (2015).

41. Boyd, M., R. \& Paull, K., D. Some practical considerations and applications of the National Cancer Institute in vitro anticancer drug discovery screen. Drug Dev. Res. 34, 91109 (1995).

42. Delgado, V., Ibacache, A., Theoduloz, C. \& Valderrama, J. A. Synthesis and in Vitro Cytotoxic Evaluation of Aminoquinones Structurally Related to Marine Isoquinolinequinones. Molecules 17, $7042-7056$ (2012).

43. Badisa, R. B. et al. Selective Cytotoxic Activities of Two Novel Synthetic Drugs on Human Breast Carcinoma MCF-7 Cells. Anticancer Res. 29, 2993-2996 (2009).

44. Liang, Ye, Yan, Chaohua \& Schor, N.F. Apoptosis in the absence of caspase 3. Oncogene 20, 6570-6578 (2001).

45. Valdameri, G. et al. Investigation of Chalcones as Selective Inhibitors of the Breast Cancer Resistance Protein: Critical Role of Methoxylation in both Inhibition Potency and Cytotoxicity. J. Med. Chem. 55, 3193-3200 (2012).

46. Akhtar, M. N. et al. Design and synthesis of chalcone derivatives as potent tyrosinase inhibitors and their structural activity relationship. J. Mol. Struct. 1085, 97-103 (2015).

47. Ebina, M., Martinez, A., Birrer, M. J. \& Linnoila, R. I. In situ detection of unexpected patterns of mutant p53 gene expression in non-small cell lung cancers. Oncogene 20, 25792586 (2001).

48. Gulhati, P. et al. Targeted inhibition of mTor signaling inhibts tumorigenesis of colorectal cancer. Clin. Cancer Res. Off. J. Am. Assoc. Cancer Res. 15, 7207-7216 (2009).

49. Morgan, T. M., Koreckij, T. D. \& Corey, E. Targeted Therapy for Advanced Prostate Cancer: Inhibition of the PI3K/Akt/mTOR Pathway. Curr. Cancer Drug Targets 9, 237249 (2009).

50. Weinberg, R. A. in The biology of cancer. (Garland Science, Taylor and Francis group, 2013).

51. Nyandoro, S. S., Nkunya, M. H. H., Josepha, C. C., Odalo, J. O. \& Sattler, I. New Glucopyranosylglyceryl-NOctenyl Adipate and Bioactivity of Retro and Condensed Chalcones from Toussaintia Orientalis. Tanzan. J. Sci. 38, 108126 (2014).

52. Weiss, J., Sauer, A., Frank, A. \& Unger, M. Extracts and kavalactones of Piper methysticum G. Forst (kava-kava) inhibit P-glycoprotein in vitro. Drug Metab. Dispos. Biol. Fate Chem. 33, 1580-1583 (2005). 


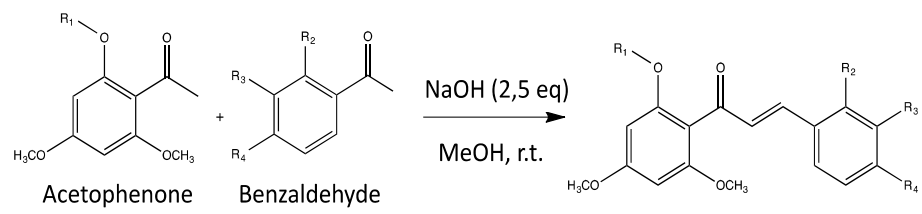

$$
\text { (1 eq) (1 eq) }
$$
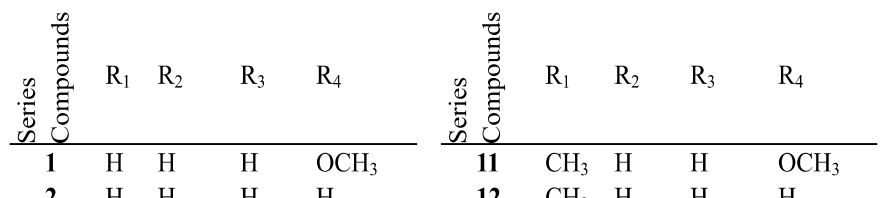

$\begin{array}{lllllllllll}2 & \mathrm{H} & \mathrm{H} & \mathrm{H} & \mathrm{H} & \mathbf{1 2} & \mathrm{CH}_{3} & \mathrm{H} & \mathrm{H} & \mathrm{H}\end{array}$

$\begin{array}{llllllllll}3 & \mathrm{H} & \mathrm{H} & \mathrm{H} & \mathrm{Cl} & \mathbf{1 3} & \mathrm{CH}_{3} & \mathrm{H} & \mathrm{H} & \mathrm{Cl}\end{array}$

$\begin{array}{llllllllll}4 & \mathrm{H} & \mathrm{H} & \mathrm{H} & \mathrm{Br} & \mathbf{1 4} & \mathrm{CH}_{3} & \mathrm{H} & \mathrm{H} & \mathrm{Br}\end{array}$

$\begin{array}{llllllllll}\mathbf{5} & \mathrm{H} & \mathrm{H} & \mathrm{H} & \mathrm{F} & \mathbf{1 5} & \mathrm{CH}_{3} & \mathrm{H} & \mathrm{H} & \mathrm{F}\end{array}$

$\begin{array}{lllllllllll}1 & 6 & \mathrm{H} & \mathrm{H} & \mathrm{H} & \mathrm{COOH} & \mathbf{1 6} & \mathrm{CH}_{3} & \mathrm{H} & \mathrm{H} & \mathrm{COOH}\end{array}$

$\begin{array}{lllllllllll}7 & \mathrm{H} & \mathrm{H} & \mathrm{H} & \mathrm{N}\left(\mathrm{CH}_{3}\right)_{2} & 2 & \mathbf{1 7} & \mathrm{CH}_{3} & \mathrm{H} & \mathrm{H} & \mathrm{N}\left(\mathrm{CH}_{3}\right)_{2}\end{array}$

$\begin{array}{llllllllll}\mathbf{8} & \mathrm{H} & \mathrm{H} & \mathrm{OCH}_{3} & \mathrm{H} & \mathbf{1 8} & \mathrm{CH}_{3} & \mathrm{H} & \mathrm{H} & \mathrm{NO}_{2}\end{array}$

$\begin{array}{llllllllllll}9 & \mathrm{H} & \mathrm{OCH}_{3} & \mathrm{H} & \mathrm{H} & \mathbf{1 9} & \mathrm{CH}_{3} & \mathrm{H} & \mathrm{OCH}_{3} & \mathrm{H}\end{array}$

$\begin{array}{lllllllllll}\mathbf{1 0} & \mathrm{H} & \mathrm{SCH}_{3} & \mathrm{H} & \mathrm{H} & \mathbf{2 0} & \mathrm{CH}_{3} & \mathrm{OCH}_{3} & \mathrm{H} & \mathrm{H}\end{array}$

$\begin{array}{lllll}21 & \mathrm{CH}_{3} & \mathrm{SCH}_{3} & \mathrm{H} & \mathrm{H}\end{array}$

\begin{tabular}{lllll}
22 & $\mathrm{CH}_{3}$ & $\mathrm{H}$ & $\mathrm{H}$ & $\mathrm{OH}$ \\
\hline
\end{tabular}

Figure 1. Reagents, conditions and structures of synthesized compounds 


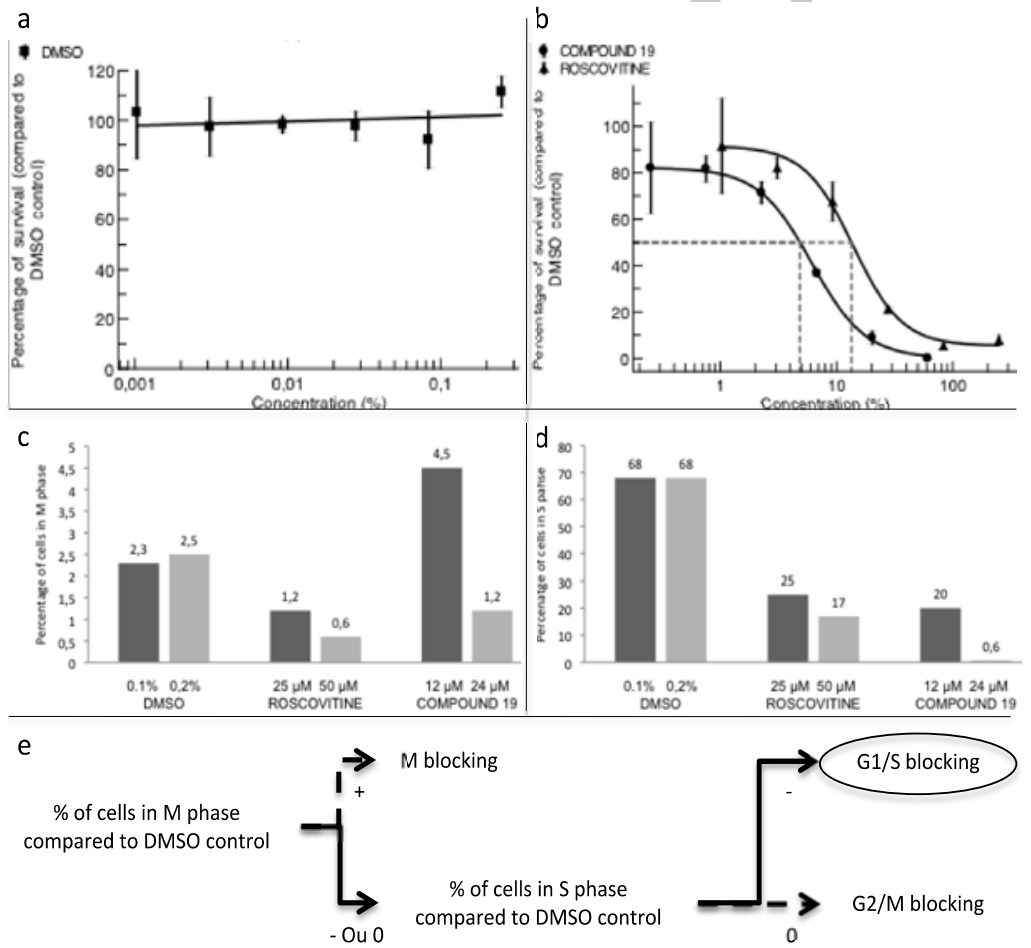

Figure 2. Cytotoxic activities: determination of $\mathrm{IC}_{50}$ and targeted cell cycle phases. (a) Dose-effect curve for DMSO (negative control), (b) Dose-effect curve for roscovitine (triangle, positive control) and compound 19 (circle), (c) MI or \% of cells in M phase at 2 concentrations of DMSO $(0.1 \%$ and $0.2 \%$, final concentrations of DMSO for roscovitine and compound 19), roscovitine and compound $\mathbf{1 9}$, (d) $\%$ of cells in S phase at 2 concentrations of DMSO $(0.1 \%$ and $0.2 \%$ ), roscovitine and compound $\mathbf{1 9}$, (e) Determination keys of targeted cell cycle phases, compound 19 and roscovitine blocked cell cycle in G1/S phase 
IC50 $\geq 20 \mu \mathrm{M}$ or inactive $\square 5<\mathrm{IC} 50>20 \mu \mathrm{M} \quad \square \mathrm{IC} 50 \leq 5 \mu \mathrm{M}$



Figure 3. Percentage of FKd in the first and second series showing no or weak $\left(\mathrm{IC}_{50}>20 \mu \mathrm{M}\right)$, strong $\left(5<\mathrm{IC}_{50}<20 \mu \mathrm{M}\right)$ or very strong cytotoxic activities $\left(\mathrm{IC}_{50}<5 \mu \mathrm{M}\right)$

$\mathrm{SI} \leq 2 \quad-2<\mathrm{SI}>10 \quad \square \mathrm{SI} \geq 10$

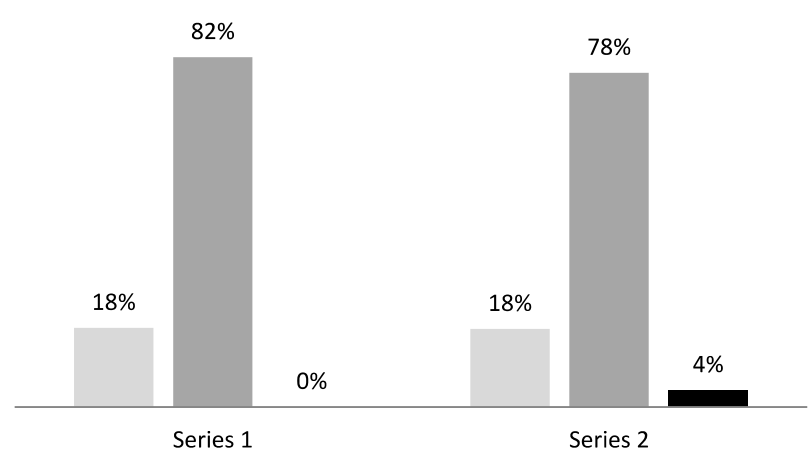

Figure 4. Percentage of interesting FKD in the first and second series showing no selectivity $(\mathrm{SI} \leq 2)$, weak selectivity $(2<\mathrm{SI}>10)$ and strong selectivity $(\mathrm{SI} \geq 10)$ for cancer cell lines. 
a

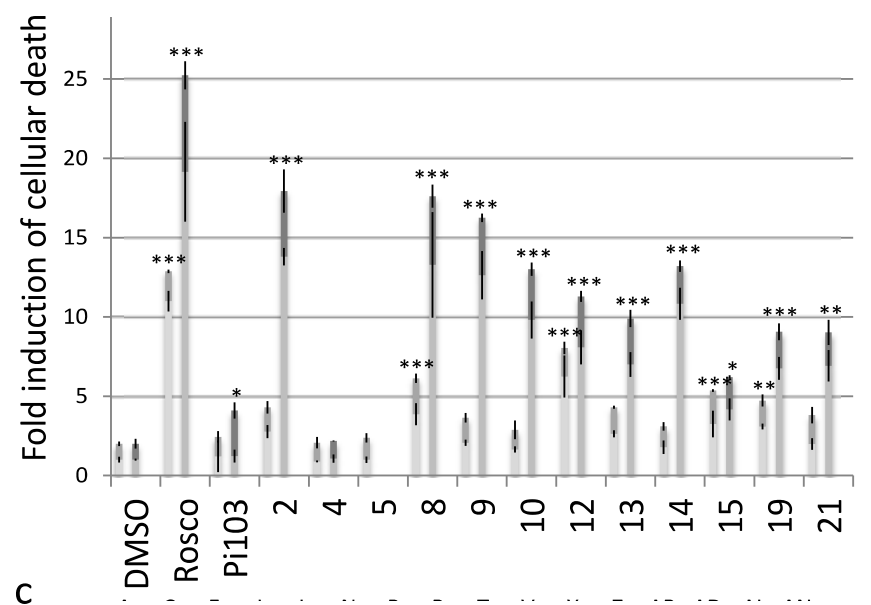

C



b
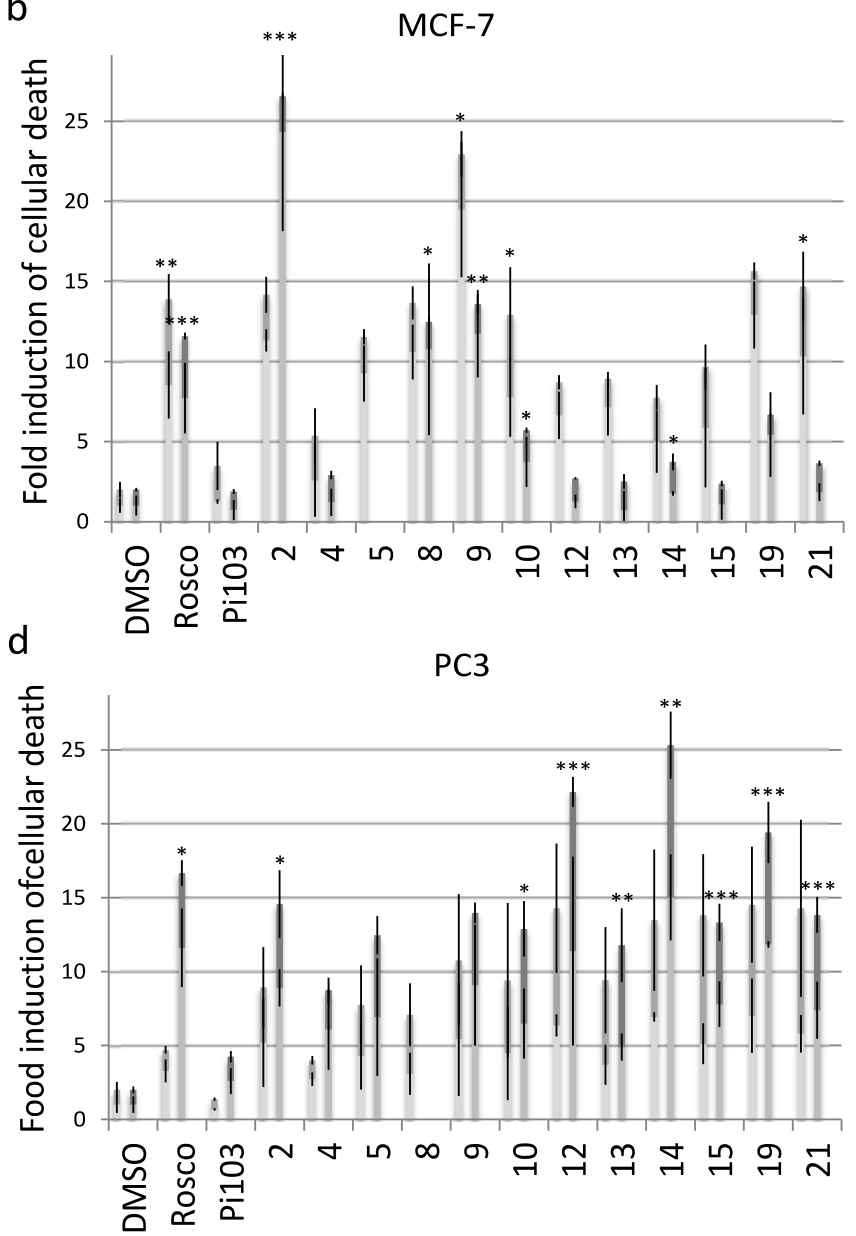

Figure 5. Fold induction of early apoptosis (fold induction of YoPro-positive cells) in pale grey and late apoptosis (fold induction of IP-positive cells) in dark grey after $24 \mathrm{~h}$ (left) and $48 \mathrm{~h}$ (right) of treatment by interesting FKd on four cancer cell lines: (a) HCT116, (b) MCF-7, (c) MDA-MB-231, (d) PC3. Results are the mean $\pm \mathrm{SD}$ from three independent experiments. The statistical analysis was performed with one-way ANOVA followed by Tukey's post hoc tests. ${ }^{*} \mathrm{P}<0.05$, 
a

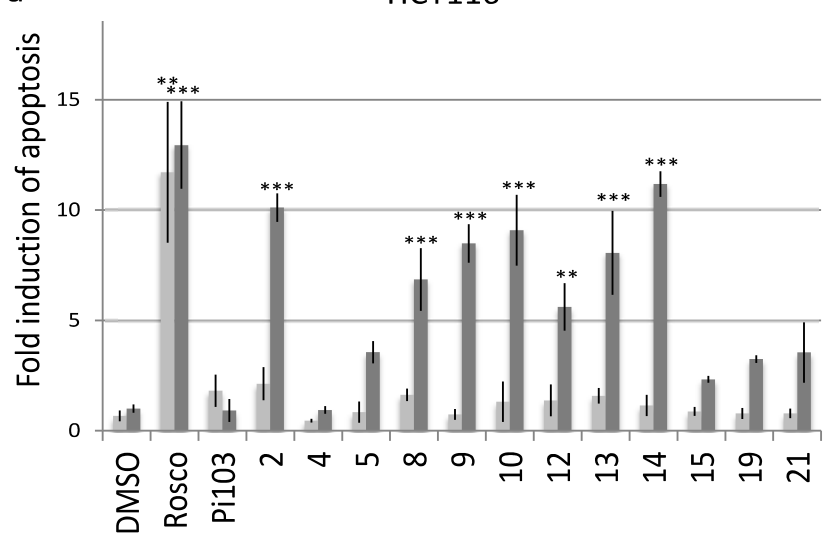

b



C

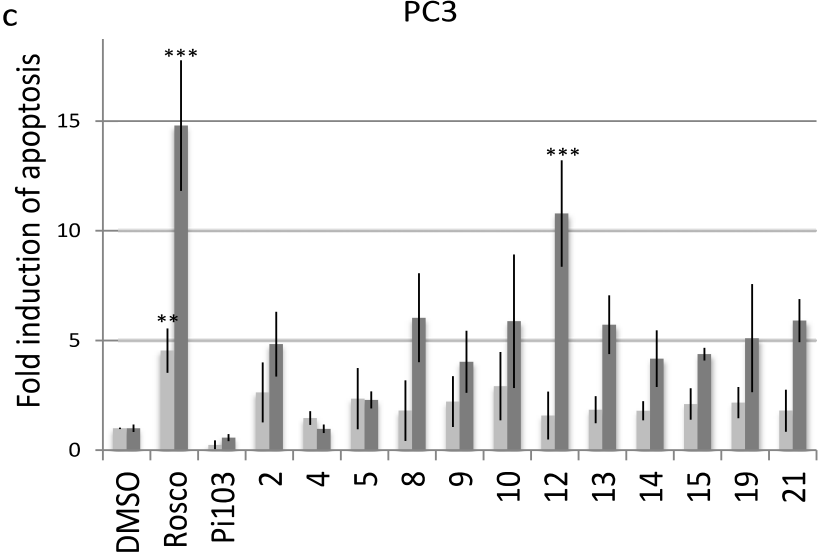

Figure 6. Fold induction of apoptosis (fold induction of CASP-positive cells) after 24h (pale grey) and 48h (dark grey) of treatments by interesting FKd on three cancer cell lines: (a) HCT116, (b) MDA-MB-231, (c) PC3. Results are the mean \pm SD from three independent experiments. The statistical analysis was performed with one-way ANOVA followed by Tukey's post hoc tests. ${ }^{*} \mathrm{P}<0.05,{ }^{* *} \mathrm{P}<0.01,{ }^{* * *} \mathrm{P}<0.001$ compared to control 
a

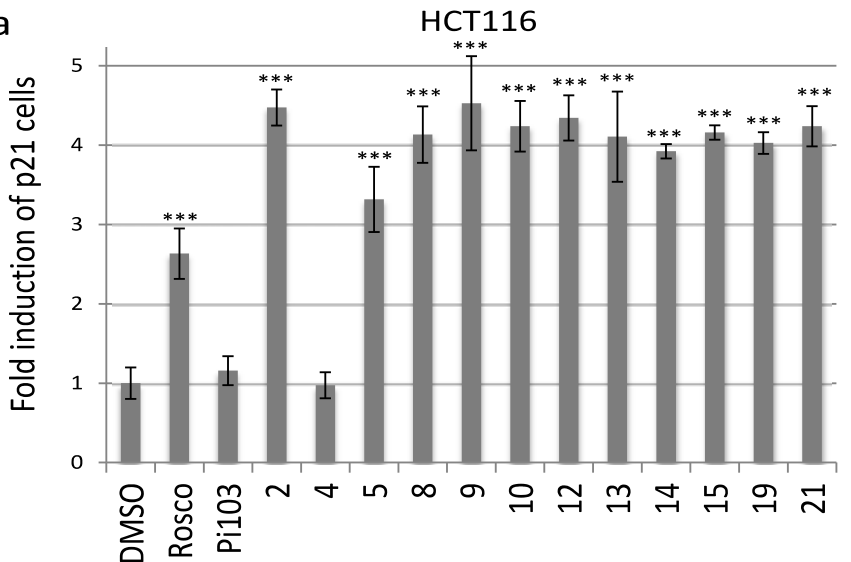

b

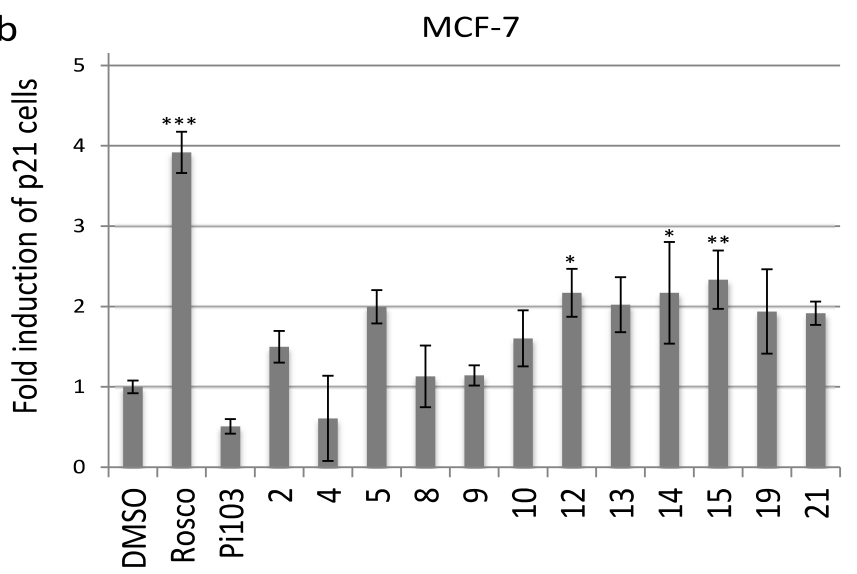

Figure 7. Fold induction of p21 cells after 48h of treatment by intesresting FKd on two p53 wild-type cancer cell lines: (a) HCT116 cells (b) MCF-7. Results are the mean \pm SD from three independent experiments. The statistical analysis was performed with one-way ANOVA followed by Tukey's post hoc tests. ${ }^{*} \mathrm{P}<0.05,{ }^{* * \mathrm{P}}<0.01,{ }^{* * *} \mathrm{P}<0.001$ compared to control 


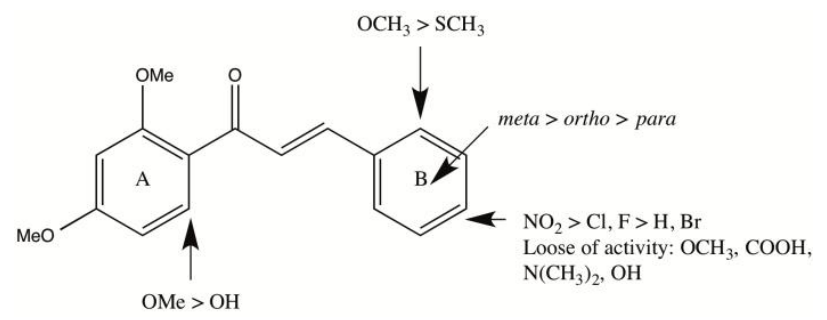

Figure 9. Synthetic scheme of SAR 